\title{
Surface-atmosphere exchange of ammonia over peatland using QCL-based eddy-covariance measurements and inferential modeling
}

\author{
Undine Zöll ${ }^{1,}{ }^{*}$, Christian Brümmer ${ }^{1}$, Frederik Schrader ${ }^{1}$, Christof Ammann $^{2}$, Andreas Ibrom ${ }^{3}$, \\ Christophe R. Flechard ${ }^{4}$, David D. Nelson ${ }^{5}$, Mark Zahniser ${ }^{5}$, and Werner L. Kutsch ${ }^{6}$ \\ ${ }^{1}$ Thünen Institute of Climate-Smart Agriculture, 38116 Braunschweig, Germany \\ ${ }^{2}$ Swiss Federal Research Station Agroscope ART, 8046, Zürich, Switzerland \\ ${ }^{3}$ Technical University of Denmark, Department of Environmental Engineering, Bygningstorvet, \\ 2800 Kgs. Lyngby, Denmark \\ ${ }^{4}$ INRA, Agrocampus Ouest, UMR1069 SAS, 35042 Rennes, France \\ ${ }^{5}$ Aerodyne Research, Inc., Billerica, Massachusetts, USA \\ ${ }^{6}$ Integrated Carbon Observation System (ICOS), Head Office, University of Helsinki, Finland \\ * previously published under my name: Undine Richter
}

Correspondence to: Undine Zöll (undine.richter@thuenen.de)

Received: 7 March 2016 - Published in Atmos. Chem. Phys. Discuss.: 16 March 2016

Revised: 16 August 2016 - Accepted: 28 August 2016 - Published: 13 September 2016

\begin{abstract}
Recent advances in laser spectrometry offer new opportunities to investigate ecosystem-atmosphere exchange of environmentally relevant trace gases. In this study, we demonstrate the applicability of a quantum cascade laser (QCL) absorption spectrometer to continuously measure ammonia concentrations at high time resolution and thus to quantify the net exchange between a seminatural peatland ecosystem and the atmosphere based on the eddy-covariance approach. Changing diurnal patterns of both ammonia concentration and fluxes were found during different periods of the campaign. We observed a clear tipping point in early spring with decreasing ammonia deposition velocities and increasingly bidirectional fluxes that occurred after the switch from dormant vegetation to $\mathrm{CO}_{2}$ uptake but was triggered by a significant weather change. While several biophysical parameters such as temperature, radiation, and surface wetness were identified to partially regulate ammonia exchange at the site, the seasonal concentration pattern was clearly dominated by agricultural practices in the surrounding area. Comparing the results of a compensation point model with our measurement-based flux estimates showed considerable differences in some periods of the campaign due to overestimation of non-stomatal resistances caused by low acid
\end{abstract}

ratios. The total cumulative campaign exchange of ammonia after 9 weeks, however, differed only in a $6 \%$ deviation with 911 and $857 \mathrm{~g} \mathrm{NH}_{3}-\mathrm{Nha}^{-1}$ deposition being found by measurements and modeling, respectively. Extrapolating our findings to an entire year, ammonia deposition was lower than reported by Hurkuck et al. (2014) for the same site in previous years using denuder systems. This was likely due to a better representation of the emission component in the net signal of eddy-covariance fluxes as well as better adapted site-specific parameters in the model. Our study not only stresses the importance of high-quality measurements for studying and assessing land surface-atmosphere interactions but also demonstrates the potential of QCL spectrometers for continuous observation of reactive nitrogen species as important additional instruments within long-term monitoring research infrastructures such as ICOS or NEON at sites with strong nearby ammonia sources leading to relatively high mean background concentrations and fluxes. 


\section{Introduction}

Increased agricultural production and energy consumption over the last century led to a dramatic increase in anthropogenic reactive nitrogen $(\mathrm{N})$ production (Erisman et al., 2008). Atmospheric $\mathrm{N}$ deposition can be a major driver of change in most natural and seminatural ecosystems and may considerably alter species composition, biodiversity, and ecosystem functioning with regard to causing nutrient imbalances. As ammonia $\left(\mathrm{NH}_{3}\right)$ mainly originates from agricultural activities, it has received more and more attention in the past 20 years (e.g., Sutton et al., 2011). It is estimated that in $200865 \mathrm{Mt} \mathrm{NH}_{3}-\mathrm{N}$ was emitted globally to the atmosphere (Sutton et al., 2013), a large proportion (60\%) of it from anthropogenic sources. Around 1910 the creation and therefore release of $\mathrm{NH}_{3}$ experienced a steep rise due to the Haber-Bosch process (Galloway et al., 2003). While ammonia emissions doubled since 1950 (Asman et al., 1998), Sutton et al. (2013) predict the emission of $132 \mathrm{MtNH}_{3}-$ $\mathrm{N} \mathrm{yr}^{-1}$ by 2100 . Ammonia is an essential part of the nitrogen cascade, with reactive nitrogen $\left(\mathrm{N}_{\mathrm{r}}\right)$ tending to accumulate in both ecosystems and atmosphere, mainly because denitrification in soils cannot balance out industrial $\mathrm{N}$ creation (Galloway et al., 2003), causing a severe environmental problem for future generations. Additionally, reactive $\mathrm{N}$ is widely spread through hydrologic and atmospheric transport processes (Galloway et al., 2003). Ammonia can cause foliar injury, increase sensitivity to drought, reduce frost hardiness, and lead to structure change in plant communities and loss in biodiversity, especially regarding sensitive nutrientpoor ecosystems like peatbogs (Krupa, 2003). Furthermore, deposited ammonia causes ecosystem acidification, fertilization, and eutrophication (Galloway et al., 2003), while air and water quality deterioration also impacts human health (Erisman et al., 2013).

Until now only little was known about the temporal and spatial variability of $\mathrm{NH}_{3}$ concentrations and exchange fluxes between different ecosystems and the atmosphere. To what extent $\mathrm{NH}_{3}$ is being emitted from plant canopies under common environmental conditions remains highly uncertain (e.g., Flechard et al., 2013). This is due to the fact that continuous half-hourly micrometeorological measurements of $\mathrm{NH}_{3}$ exchange, e.g., based on the aerodynamic gradient or eddy-covariance (EC) technique, have largely remained experimental and were limited to selected research sites and to measurement campaigns of typically a few weeks to a few months due to technical complexity and to the large equipment and operational costs involved (e.g., Sutton et al., 2007; Flechard et al., 2011; Marx et al., 2012; Brümmer et al., 2013). Other well-established techniques like denuder, impinger, or filter sampling in combination with ion chromatography analysis usually provide concentration values and flux rates at poor time resolution and require labor- and costintensive chemical analyses (e.g., Dämmgen and Zimmerling, 2002; Tang et al., 2009; Hurkuck et al., 2014). Over the last few years, substantial progress has been made in the use of tunable diode laser absorption spectrometers (TDLASs) and quantum cascade lasers (QCLs). The precision and fast response of these approaches have allowed first EC measurements of field-scale $\mathrm{N}_{2} \mathrm{O}$ and $\mathrm{CH}_{4}$ fluxes (Denmead et al., 2010; Kroon et al., 2010; Neftel et al., 2010; Merbold et al., 2014), and they are expected to become a standard method within integrated observation networks such as ICOS in Europe or NEON in North America. EC measurements of $\mathrm{NH}_{3}$ fluxes, however, have been extremely limited and are still subject to considerable uncertainty (Famulari et al., 2004; Ellis et al., 2010; Sintermann et al., 2011; Ferrara et al., 2012) mainly due to issues regarding the tube inlet design, sampling high-frequency flux losses, and tube wall and air chemistry (e.g., Marx et al., 2012, and references therein).

In this study, we demonstrate the applicability of a QCL absorption spectrometer to continuously and quickly measure turbulent fluctuations at background-level $\mathrm{NH}_{3}$ concentrations and thus the net exchange between a seminatural peatland ecosystem and the atmosphere, with the EC technique. Specifically, we (1) test the QCL performance to measure $\mathrm{NH}_{3}$ concentration fluctuations and calculate $\mathrm{NH}_{3}$ fluxes and net deposition during the observation period, (2) investigate the biophysical controls on $\mathrm{NH}_{3}$ concentrations and fluxes, and (3) compare the measured fluxes with results from a local application of a two-layer $\mathrm{NH}_{3}$ canopy compensation point model using the parameterization of Massad et al. (2010). The general objective is to better understand the mechanisms of peatland-atmosphere $\mathrm{NH}_{3}$ exchange under the influence of highly intensive agricultural land management in the surrounding area.

\section{Materials and methods}

\subsection{Site description and local climate}

Tower-based fast response measurements of ammonia concentrations were conducted from 18 February to 8 May 2014 at an ombrotrophic, moderately drained peatland located in northwestern Germany near the city of Meppen $\left(52^{\circ} 39^{\prime} 21.25^{\prime \prime} \mathrm{N}, 7^{\circ} 11^{\prime} 0.17^{\prime \prime} \mathrm{E} ; 14 \mathrm{~m}\right.$ a.s.1.). The site is surrounded by intensive agricultural land and livestock holdings. Local vegetation is dominated by bog heather (Erica tetralix), purple moor grass (M. caerulea), and cotton grass (Eriophorum vaginatum, Eriophorum angustifolium) and is further characterized by some smaller, mostly solitary, trees like birches (B. pubescens) and Scots pines (Pinus sylvestris). The peat layer depth is approx. $4 \mathrm{~m}$. The area around the tower has a fetch of $650 \mathrm{~m}$ including some small paths, tree lines, and hedgerows. Facing towards the main wind direction (SSW) $230 \mathrm{~m}$ can be regarded as totally homogenous. Details on fetch and footprint analysis are given in Hurkuck et al. (2014). 
From 1981 to 2010 the annual average air temperature $\left(T_{\mathrm{a}}\right)$ and the mean annual precipitation in the area were $10.0^{\circ} \mathrm{C}$ and $800 \mathrm{~mm}$, respectively (German Weather Service, station Lingen, 2015). For the respective months of observation (February to May), the long-term average air temperatures were $2.7,5.7,9.3$, and $13.6^{\circ} \mathrm{C}$, respectively. Except for May, monthly mean air temperatures in 2014 were higher $(4.1,6.3$, 10.9 , and $12.3^{\circ} \mathrm{C}$ ) than the 30 -year averages. Monthly precipitation $(36,31,39$, and $124 \mathrm{~mm}$ ) was lower in February, March, and April than the long-term observations (53, 67, 45 , and $58 \mathrm{~mm})$. As most of the precipitation was recorded after the campaign on 8 May, the measurement period was considerably drier than the long-term mean.

\subsection{Measurements of ammonia and microclimate}

Ammonia concentrations were measured at high temporal resolution with a QCL absorption spectrometer (model mini QC-TILDAS-76) from Aerodyne Research, Inc. (ARI, Billerica, MA, USA). They were recorded as $\mathrm{mol} \mathrm{NH}_{3}$ per mol dry air, also termed mixing ratio, due to an online internal correction for water vapor dilution provided by the QCL. Laser detectors were thermoelectrically cooled at $25^{\circ} \mathrm{C}$. A $76 \mathrm{~m}$ path length and $0.5 \mathrm{~L}$ multiple pass absorption cell for sampling at an operation pressure of approx. 40 Torr was used. The QCL is able to offer up to $10 \mathrm{~Hz}$ resolution with the detection limit in the sub-ppb range (McManus et al., 2008). The main frequencies of the flux contributing eddies were in a range of 0.01 to $1 \mathrm{~Hz}$. Precision, i.e., measurement sensitivity, of the instrument is $0.042,0.021,0.016$, and $0.010 \mathrm{ppb}$ in $1,10,20$, and $60 \mathrm{~s}$, respectively. Along with its compact design, the QCL forms an appropriate basis for EC measurements in the field (Ellis et al., 2010; Ferrara et al., 2012). A dry vacuum scroll pump (TriScroll 600, Agilent Technologies, Santa Clara, USA) was used to transport the sample air with a flow rate of approx. $17 \mathrm{~L} \mathrm{~min}^{-1}$ through $3 \mathrm{~m}$ long tubing ( $1 \mathrm{~cm}$ inner diameter) to the laser cell and back outside through an exhaust device. For further conceptual details see McManus et al. (2008) and Zahniser et al. (2005) as well as Ellis et al. (2010) for a performance test.

To prevent damage to the laser cell from particles, it is necessary to filter the ambient air. Because of the stickiness of $\mathrm{NH}_{3}$ and its high reactivity, it is not possible to use any conventional membrane filter. Aerodyne Research, Inc. developed a specific inertial inlet (Fig. 1) that removes particles with an aerodynamic diameter larger than $300 \mathrm{~nm}$ and that reduces pressure inside tubing and laser cell. After a short PTFE inlet, a critical orifice made of glass ensures that the pressure in the system is decreased to a range of approx. 5.3 to $8 \mathrm{kPa}$, which significantly reduces wall adsorption effects (Warland et al., 2001) and is required for the operation of the laser cell. After passing the critical orifice, the sample air is forced to make a sharp turn, thereby losing $10 \%$ of its volume, going straight to the pump, and approx. $50 \%$ of the particles (>300 nm; Ellis et al., 2010; Ferrara et al.,
2012; von Bobrutzki et al., 2010). Heating the inertial inlet box (at approx. $40^{\circ} \mathrm{C}$ ) and the anti-adhesive PFA tubing that leads the sample air to the QCL's analyzer cell minimize water condensation or absorption (Massman and Ibrom, 2008; Ibrom et al., 2007), thus avoiding interactions of ammonia with surfaces (Walker et al., 2006; Norman et al., 2009; Ellis et al., 2010). Ellis et al. (2010) compared different tubing variants and reported significant improvement when using heated tubing at $40{ }^{\circ} \mathrm{C}$, which reduced unintended interactions to around $10 \%$ at $30 \mathrm{ppb}$. A side effect is that at low atmospheric pressures $\mathrm{NH}_{4} \mathrm{NO}_{3}$ aerosols can be volatilized, if not removed by the inertial inlet, and thereby produce $\mathrm{NH}_{3}$. DELTA (DEnuder for Long-Term Atmospheric sampling; e.g., Tang et al., 2009) denuder measurements (details below) showed a $\mathrm{NH}_{4}^{+}$to $\mathrm{NH}_{3}$ ratio of 0.17 up to 0.24 during the campaign. Assuming that $100 \%$ of the $\mathrm{NH}_{4}^{+}$aerosols passed the inlet and were volatilized, there was on average an overestimation of $21 \%$ of $\mathrm{NH}_{3}$ concentration, which is the same rate Walker et al. (2006) found in their investigation and is an acceptable compromise between $\mathrm{NH}_{3}$ loss due to wall sorption effects and ammonia alterations through $\mathrm{NH}_{4} \mathrm{NO}_{3}$ volatilization. This affects not only the concentration but also the flux because $\mathrm{NH}_{4} \mathrm{NO}_{3}$ particles are also deposited. In this study, we performed calibration with zero air every $8 \mathrm{~h}$, i.e., at 00:00, 08:00, and 16:00 local time for $60 \mathrm{~s}$ per interval (data not shown) as well as internal system calibration through the laser itself by aligning the $\mathrm{NH}_{3}$ absorption peak of the sampled air to the standard of the HITRAN database (Rothman et al., 2009).

An ultrasonic anemometer (model R3, Gill Instruments, Lymington, UK) was installed at $2.5 \mathrm{~m}$ above ground. The inertial inlet box was mounted next to it on the northern side, a less common wind direction at the site $(5.6 \%$ of the campaign), placing the sample air inlet westward $40 \mathrm{~cm}$ below the center of the sonic anemometer array. To protect the inlet from rain, a tee inlet was attached, which allowed to feed in calibration gas (see above).

Additional measurements of $\mathrm{NH}_{3}$ concentrations with monthly time resolution were conducted by means of passive samplers (e.g., Dämmgen et al., 2010) and DELTA denuder. A detailed description of the measurement setup of meteorological parameters such as air and soil temperature, radiation components, precipitation, water table depth, as well as the operation of carbon dioxide and water vapor EC measurements is presented in Hurkuck et al. (2014, 2016).

\subsection{Data acquisition, analysis, and flux calculation}

Sonic anemometer data were recorded by the EddyMeas software, which is an embedded application of the software package EddySoft (Kolle and Rebmann, 2009). The QCL was controlled by Aerodyne's TDL Wintel software with ammonia concentration data being recorded at a frequency of $10 \mathrm{~Hz}$ on the QCL computer. Anemometer and concentration time series needed alignment to a reference timestamp before 


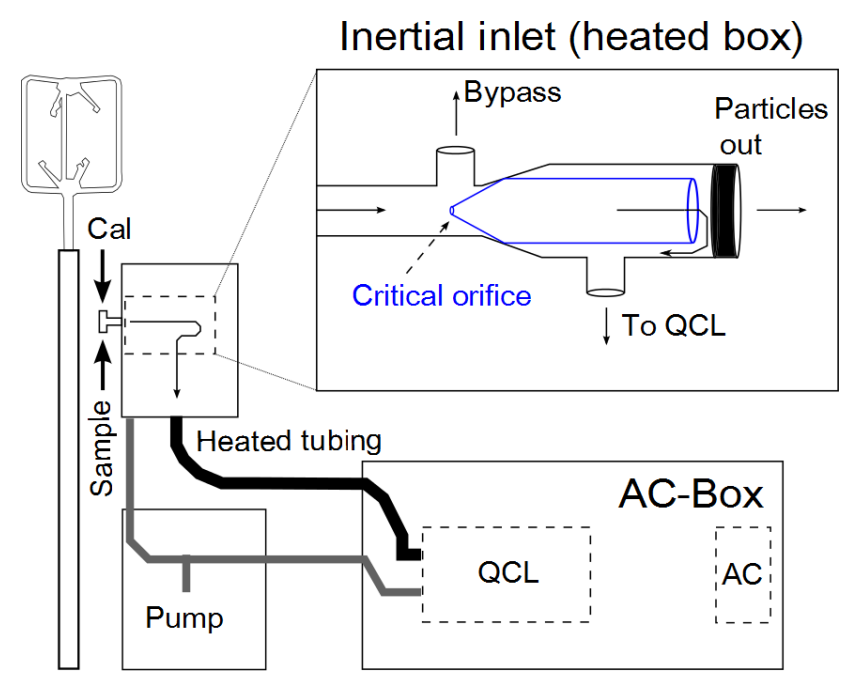

Figure 1. Schematic overview of the measurement setup. An ultrasonic anemometer (measurement height $2.5 \mathrm{~m}$ ) is mounted closely to the heated "inertial inlet" box $(39 \mathrm{~cm} \times 34 \mathrm{~cm} \times 21 \mathrm{~cm})$ containing a critical glass orifice to reduce the pressure regime inside the sample line (total length $3.5 \mathrm{~m}$ ) to 5.3 to $8 \mathrm{kPa}$. After passing the critical orifice, a sharp turn of the flow path leads to a reduction of particles $(>300 \mathrm{~nm})$ of approx. $50 \%$, thereby reducing unintentional chemical interactions. The heated tubing (black tube) leads the sample air (flow rate $=$ approx. $17 \mathrm{~L} \mathrm{~min}^{-1}$ ) to the quantum cascade laser (QCL), which is housed in an air-conditioned (AC) box. The bypass air and the particle outflow are combined in the inertial inlet box and together sucked to the pump (left part of the grey tube).

the software EddyPro (LI-COR Inc.) could be used to compute half-hourly exchange fluxes. Block averaging and 2-D coordinate rotation were applied.

The effective time lag between the data series of the vertical wind speed $(w)$ and the $\mathrm{NH}_{3}$ concentration was determined by searching the maximum (absolute) covariance as a function of the time shift. A strong and irregular drift in the form of a sawtooth wave was found for the lag time of maximum covariance (Fig. 2b), which is attributed to diverging drifts of the system clocks of the sonic anemometer's data acquisition computer and the QCL clock. Thus, the drifting time lag was divided into subsections (one for each tooth) and a linear trend was fitted to the apparent time lag in each section. Then each half-hourly $\mathrm{NH}_{3}$ time series was shifted with this estimated time lag using a specifically designed Rscript (R Core Team, 2012) resulting in near-zero time lags in the corrected datasets. After a further covariance maximization procedure, a smaller, less varying, time lag remained. In EddyPro a range of -2 to $4 \mathrm{~s}$ was chosen.

The ogive method from Ammann et al. (2006) was applied to empirically investigate the high-frequency damping of $\mathrm{NH}_{3}$ concentration measurements which usually occurs due to imperfect turbulent flow regime and possible wall sorption effects in the sampling line. Cumulative cospectra
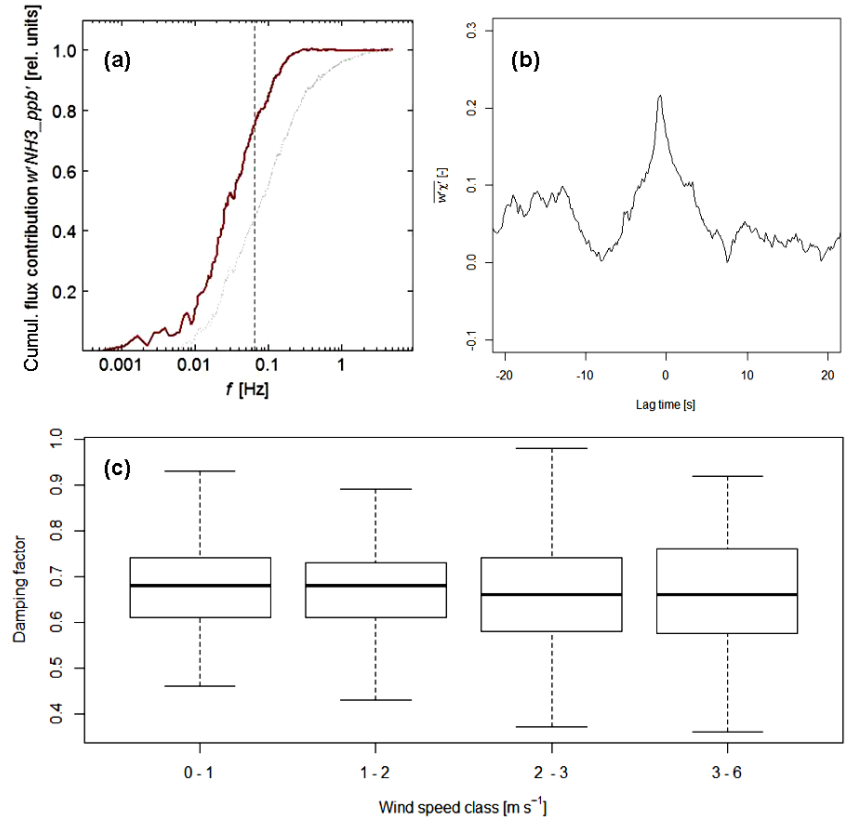

Figure 2. (a) Normalized flux ogives, i.e., cumulative cospectra, of sensible heat (grey) and $\mathrm{NH}_{3}$ flux (red). Data were recorded on 18 February 2014, 15:30-16:00. The vertical dotted line indicates the frequency at which the two ogives are compared to determine the empirical high-frequency damping factor for the $\mathrm{NH}_{3}$ flux. (b) Example of a covariance function of vertical wind speed and ammonia concentration (19 February 2014, 14:30), after correction, peaking at a time lag of $0 \mathrm{~s}$. (c) Variation of the damping factor separated by wind speed classes. Bold horizontal lines in box plots show the median; fine horizontal lines indicate lower and upper quartile values; whiskers represent 1.5 times the interquartile range.

of $\overline{w^{\prime} \mathrm{NH}_{3}^{\prime}}$ were scaled to the corresponding $\overline{w^{\prime} T^{\prime}}$ cospectra in the medium-low-frequency range (see example ogives in Fig. 2a) for quality filtered cases. The resulting relative deviations at the high-frequency end are quantitative measures of the flux damping factor. A median damping factor of 0.67 was found which is similar to the damping factors that Ferrara et al. $(2012,2016)$ reported for their $\mathrm{NH}_{3}$ QCL system. As clear dependency of neither the damping factor on horizontal wind speed (Fig. 2c) nor atmospheric stability could be observed, a constant correction factor of $1 / 0.67$ was applied to all $\mathrm{NH}_{3}$ flux values as a simplified approach. The random uncertainty of the correction factor was estimated to $15 \%$, but a potential systematic deviation (part of the damping not appropriately detected by the ogive method) cannot be fully excluded.

The random flux error was computed according to the method of Finkelstein and Sims (2001) and the corresponding limit of detection was determined from Langford et al. (2015) as 1.96 times the flux error (95\% confidence limit), resulting in a median value of $7.75 \mathrm{ng} \mathrm{N} \mathrm{m}^{-2} \mathrm{~s}^{-1}$. Alternatively, an upper flux detection limit for half-hourly values can be calculated by using only nighttime data under stationary 
conditions (3-7 $\mathrm{m} \mathrm{s}^{-1}$ wind speed) and wind from the westsouthwestern sector, where local ammonia sources were negligible and concentrations were low $(<15 \mathrm{ppb})$. The standard deviation was $16.5 \mathrm{ng} \mathrm{N} \mathrm{m}^{-2} \mathrm{~s}^{-1}$, so the $2 \sigma$ uncertainty range is $33.0 \mathrm{ng} \mathrm{N} \mathrm{m}^{-2} \mathrm{~s}^{-1}$.

To guarantee a high level of data quality, fluxes were flagged according to criteria presented in Mauder and Foken (2006). Data from 11 to 28 April were excluded from analysis due to several technical difficulties such as power outages, pump failure, or insufficient temperature control inside the analyzer housing. 33.9, 44.3, and $10.9 \%$ of data were flagged with grade 0,1 , and 2 , respectively. Data with quality flags 0 and 1 were used for further analysis, while flag 2 data were discarded. Because the stationarity tests included in the flagging protocol by Mauder and Foken (2006) might not be applicable for $\mathrm{NH}_{3}$ due to possibly higher variability of the flux over short timescales, flag 1 was generally not discarded. The remaining $10.9 \%$ of data were not used due to insufficient turbulence $\left(u_{*}<0.1 \mathrm{~m} \mathrm{~s}^{-1}\right)$. The data gaps (except for the lost data in April) were filled with the mean diurnal variation (window $= \pm 5$ days) method (Falge et al., 2001; Moffat et al., 2007). Campaign data were grouped into four periods (Table 1) of 9 to 25 days depending on different concentration patterns and meteorology.

\subsection{Modeling ammonia exchange}

A state-of-the-art dry deposition inferential model driven by measured $\mathrm{NH}_{3}$ concentrations and local micrometeorological conditions was applied to assess plausibility of the flux measurements. We used the parameterization of a two-layer canopy compensation point model from Massad et al. (2010), which simplifies to a one-layer big leaf model for unmanaged ecosystems (i.e., no soil layer is considered explicitly below the canopy; cf. Nemitz et al., 2000). Aerodynamic, quasi-laminar, and cuticular resistance $\left(R_{\mathrm{a}}(z-d)\right.$, $R_{\mathrm{b}}$, and $R_{\mathrm{W}}$, respectively) were parameterized as described in Massad et al. (2010) for seminatural/moorland vegetation as well as the stomatal compensation point ( $\mathrm{N}$-input dependent). Stomatal resistance $\left(R_{\mathrm{S}}\right)$ was modeled using the simple global radiation and temperature-dependent formulation of Wesely (1989, see Supplement for further details), with a minimum stomatal resistance for $\mathrm{H}_{2} \mathrm{O}$ of $200 \mathrm{~s} \mathrm{~m}^{-1}$, since detailed measurements of vegetation characteristics - which are necessary for more complex approaches (e.g., Emberson et al., 2000) - were not available for the study period. $R_{\mathrm{S}}$ and $R_{\mathrm{W}}$ were calculated with temperature and relative humidity at the mean notional height of trace gas exchange, estimated from measurements at the reference height and measured turbulent sensible and latent heat fluxes as described in Nemitz et al. (2009).

\section{Results and discussion}

\subsection{Diurnal and seasonal pattern of ammonia concentrations}

On a half-hourly basis, ammonia concentrations ranged from 2 to $85 \mathrm{ppb}$ with short-term $(10 \mathrm{~Hz})$ maxima reaching up to $110 \mathrm{ppb}$. The highest values were found at the beginning of March (period II) and at the beginning of April (end of period III), which coincided well with the peak of fertilization activities on nearby agricultural fields, including the spreading of organic manures from livestock farming (Fig. 3; for details on farming practices see Hurkuck et al., 2014). The base concentration level outside the fertilization periods ranged mostly between 7 and $15 \mathrm{ppb}$ and is well represented by mean values of periods I and IV.

The highest mean diurnal variability of ammonia concentrations was found in period II with peak concentrations being observed in the late afternoon ( $>30 \mathrm{ppb}$ from 5 to 15 March; Fig. 4). Concentrations were lowest at night during the whole observation period. While in period III the average mean diurnal course exhibited less variability than in period II, almost stable concentrations at a low level (7 to $12 \mathrm{ppb}$ ) were found in periods I and IV.

The frequency distributions of wind directions and ammonia concentrations for the whole observation period are shown in Fig. 5. The typical main wind direction from the 200 to $280^{\circ}$ sector is clearly visible. However, only the lowest concentrations ( $<15 \mathrm{ppb}$, average for $10^{\circ}$ wind sectors) were observed under southwesterly winds, whereas peak concentrations were found under winds from the east and northeast. This finding is consistent with observations from previous years using denuder systems (cf. Hurkuck et al., 2014). The reason for the concentration dependency on wind direction is the land use in close vicinity to the measurement site. While southwest of the tower and outside the protected zone, the area is characterized by active peat cutting, thus no elevated ammonia concentrations can be expected, east and northeast of the tower a number of farm houses with livestock buildings, manure storage areas, and adjacent fertilized land are located in a distance of approx. $2 \mathrm{~km}$. The pattern of Fig. 5 is also revealed in the progression of wind direction and concentrations over time (data not shown). At the beginning of the campaign, i.e., period I and early period II, the predominant wind direction was south and southwest while concentrations were relatively low (Fig. 3). Later on, i.e., from late period II onwards, wind direction was much more variable with sporadic episodes from the northeastern sector, when peak concentrations between 60 and $110 \mathrm{ppb}$ occurred. Despite the fact that frequent winds from the northeast were recorded in period IV, it was also the time of the lowest concentration levels $\left(\bar{c}_{\mathrm{NH}_{3}}=8.0 \mathrm{ppb}\right)$. This is an indication that the main fertilization activities on the adjacent fields had been terminated during that time. 
Table 1. Characterization for four subperiods of the measurement campaign (I to IV) with different $\mathrm{NH}_{3}$ concentration $\left(c_{\mathrm{NH}_{3}}\right.$, mean, standard deviation, maximum, and minimum) and weather regimes (mean air temperature, $\bar{T}_{\mathrm{a}}$, sum of precipitation, $P$, and net radiation, $R_{\mathrm{n}}$ ).

\begin{tabular}{llrrrrrrrr}
\hline Period & Time & $n$ & $\begin{array}{r}\bar{c}_{\mathrm{NH}_{3}} \\
(\mathrm{ppb})\end{array}$ & $\begin{array}{r}\mathrm{SD} \text { of } c_{\mathrm{NH}_{3}} \\
(\mathrm{ppb})\end{array}$ & $\begin{array}{r}\text { Min } c_{\mathrm{NH}_{3}} \\
(\mathrm{ppb})\end{array}$ & $\begin{array}{r}\text { Max } c_{\mathrm{NH}_{3}} \\
(\mathrm{ppb})\end{array}$ & $\begin{array}{r}\overline{T_{\mathrm{a}}} \\
\left({ }^{\circ} \mathrm{C}\right)\end{array}$ & $\begin{array}{r}P \\
(\mathrm{~mm})\end{array}$ & $\begin{array}{r}R_{\mathrm{n}} \\
\left(\mathrm{MJ} \mathrm{m}^{-2} \mathrm{~d}^{-1}\right)\end{array}$ \\
\hline I & Feb 18-Mar 04 & 643 & 11.3 & 5.6 & 1.2 & 34.7 & 4.5 & 6.4 & 1.71 \\
II & Mar 05-Mar 15 & 528 & 22.2 & 12.1 & 3.4 & 87.8 & 6.3 & 3.7 & 4.86 \\
III & Mar 16-Apr 10 & 1296 & 16.5 & 11.7 & 2.2 & 87.4 & 8.6 & 35.5 & 5.19 \\
IV & Apr 29-May 07 & 450 & 8.0 & 4.2 & 1.7 & 21.0 & 10.3 & 15.5 & 8.14 \\
\hline
\end{tabular}

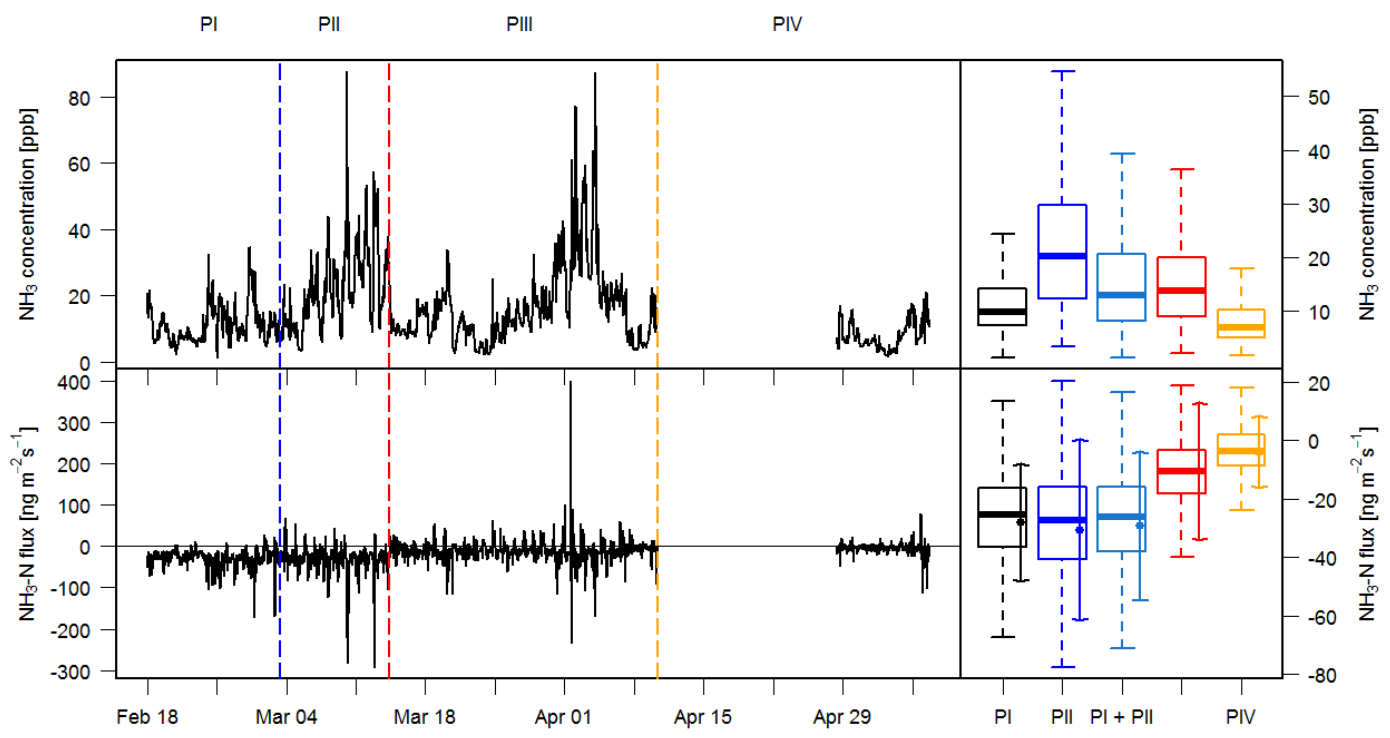

Figure 3. Half-hourly measured ammonia concentrations and fluxes. Vertical lines indicate beginning of periods listed in Table 1. Each period is represented by a box plot with bold horizontal lines showing the median, fine horizontal lines indicating lower and upper quartile values, whiskers representing 1.5 times the interquartile range, and dots with arrows indicating the mean and standard deviation.

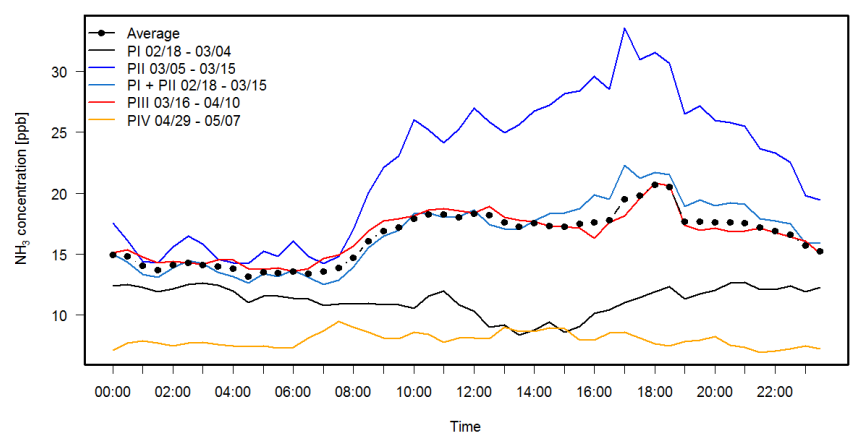

Figure 4. Mean diurnal variation of ammonia concentrations separated into different periods. Dates are given as month/day.

Similarly diurnal variability of ammonia concentrations with peak values during afternoon over a variety of ecosystems has been observed by other authors (e.g., Sutton et al., 2000; Wolff et al., 2010). There are most likely several reasons for the observed pattern in this study. First and foremost, concentration levels are highly influenced by agricultural ac- tivities in the surrounding area. Farmers usually fertilize their land during the day, thereby causing ammonia volatilization, which is then transported and detected at the study site. With a stable nighttime planetary boundary layer, ammonia in the lower atmosphere is likely being deposited, causing decreasing concentrations. With no further penetration from higher layers containing higher loads, concentrations remain low from midnight to sunrise (Fig. 4). When temperatures rise, turbulent mixing of the planetary boundary layer starts and vertical exchange with higher layers increases, which, consequently, leads to rising ammonia concentrations over the day. In contrast, continuous sources like mechanically ventilated stables could cause an opposite pattern with the planetary boundary layer acting as a lid and leading to a concentration build up at night. As no information was available of ventilation types of stables, we assume that land-applied manure during the day dominates the concentration signal in Fig. 4. The conspicuous afternoon peak cannot be explained by turbulent mixing, but it is strongly linked to the northeastern wind sector, where agricultural sources are closest (approx. $1.5 \mathrm{~km}$ distance, see also Fig. S1 in the Supplement). There- 

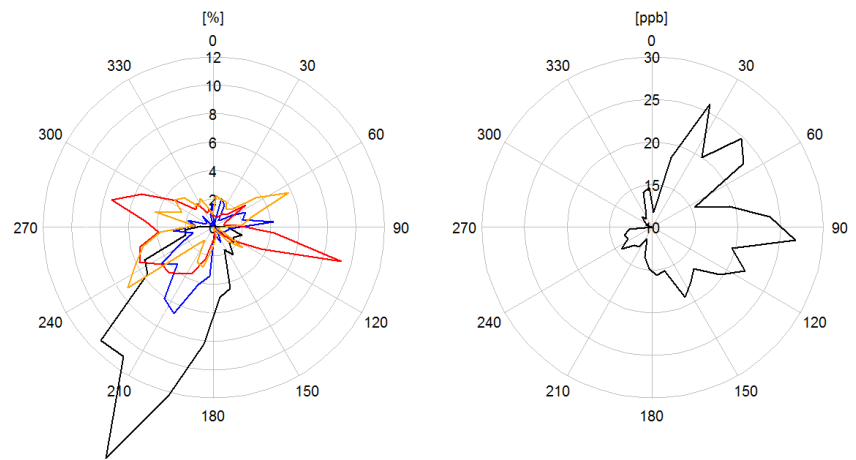

Figure 5. Frequency distribution of wind direction for each period (left panel: PI (18 February-4 March) in black, PII (5-15 March) in blue, PIII (16 March-10 April) in red, PIV (29 April-7 May) in orange) and ammonia concentration (right panel) for each $10^{\circ}$ wind sector.

fore this is assumed to be an artifact caused by these agricultural point sources.

Beside the strong influence of agricultural management on seasonal concentration variability, temperature is usually a substantial driver. Higher temperature indirectly leads to higher $\mathrm{NH}_{3}$ concentrations (Fig. 7), because it is often related to low relative humidity and thus favors ammonia release from the condensed phase towards the gas phase. However, increasing air temperature can also be linked to lower $\mathrm{NH}_{3}$ concentrations, especially observed in this study in late April and early May (period IV). With higher temperature a larger amount of acidic gas or particle species are present in the atmosphere, which usually leads to reactions of ammonia to ammonium salts such as ammonium nitrate (Kim et al., 2011). We observed higher $\mathrm{NH}_{3}$ concentrations when it was dry and/or cold, whereas rainy conditions led to lower ammonia concentration levels, which confirms findings reported by Mosquera et al. (2001). In our study, high concentrations were at the same time triggered by local sources northeast of the tower as described above. This phenomenon was particularly observed in the second half of period III under decreasing air temperatures.

Another driver for the observed concentration pattern might be leaf surface wetness. Peatlands in general, particularly during colder parts of the year, are moist environments where ammonia can easily be taken up by wet surfaces. However, it is released back to the atmosphere when surface water, e.g., dew, evaporates during morning and midday hours (Walker et al., 2006; Wentworth et al., 2014; Flechard et al., 1999; Wu et al., 2009; Burkhardt et al., 2009), which then causes again rising ammonia concentrations as observed in this study (Fig. 4). Other authors observed the concentration peak earlier in the morning, e.g., Walker et al. (2006) and Wolff et al. (2010), at arable land and grassland, respectively. The observed peak in our study might have been shifted because of the much higher humidity at our peatland site, indi- cated by small water pools, causing a longer duration of the evaporation process.

The monthly integrated ammonia concentration of $16.8 \mathrm{ppb}$ in March from QCL measurements was in good agreement with those values measured by DELTA denuder and passive samplers. The latter approaches resulted in 14.5 and $15.2 \mathrm{ppb}$ for DELTA and passive samplers, respectively, indicating their robustness and validity as low-cost methodologies for long-term air quality monitoring. As the time of exposure of DELTA denuders and passive samplers was not consistent with our QCL measurements due to instrument failures and campaign duration in February, April, and May, as well as due to highly variable concentrations during that time, we could not directly compare QCL numbers with those from the monthly integrating methods.

\subsection{Ammonia exchange and its biophysical controls}

Half-hourly measured ammonia fluxes ranged mainly within -80 and $20 \mathrm{ng} \mathrm{N} \mathrm{m}^{-2} \mathrm{~s}^{-1}$ with only very few values as low as -300 and as high as $300 \mathrm{ng} \mathrm{N} \mathrm{m}^{-2} \mathrm{~s}^{-1}$ (upward fluxes positive, Fig. 3, lower panel). On average the peatland was a sink with a mean flux of $-17.4 \mathrm{ng} \mathrm{N} \mathrm{m}^{-2} \mathrm{~s}^{-1}$. At the beginning of the campaign (periods I and II), ammonia deposition was consistently recorded ( $<-20 \mathrm{ng} \mathrm{N} \mathrm{m}^{-2} \mathrm{~s}^{-1}$; Fig. 3), while in periods III and IV the average deposition decreased to values $>-10 \mathrm{ng} \mathrm{N} \mathrm{m}^{-2} \mathrm{~s}^{-1}$ and the exchange became clearly bidirectional.

We observed considerable diurnal variability in ammonia fluxes throughout the campaign. The average diurnal flux showed moderate uptake around $-25 \mathrm{ng} \mathrm{N} \mathrm{m}^{-2} \mathrm{~s}^{-1}$ from midnight to 10:00, near-neutral exchange around noon, and highest uptake of $-40 \mathrm{ng} \mathrm{N} \mathrm{m}^{-2} \mathrm{~s}^{-1}$ in the late afternoon and early evening hours (Figs. 6 and 7). Separated by episodes, period II showed the largest amplitude, whereas period IV revealed only little variability over the daily course. Separated by surface wetness, considerably higher uptake was observed in the late afternoon and early evening when there was no precipitation recorded at the site than during times when it was raining. Furthermore, ammonia exchange shifted from around 0 to net emissions at noon during rain events. Typically rain events were mostly associated with winds from the southwest, where the influence of the agriculture is lowest. We also used the elapsed time after the last recorded rain as a proxy for leaf surface wetness (Fig. 6). We found that higher ammonia uptake coincided with a larger number of days passed since last rain.

Springtime ammonia uptake at sites that were highly influenced by fertilization and other local sources of ammonia in the surrounding area has been reported earlier, e.g., by Mosquera et al. (2001), who found considerable average deposition fluxes at their seminatural grassland site. Beside management, they showed that higher surface wetness in spring amplified local ammonia deposition, while net emission was typically found only in summer (see also 

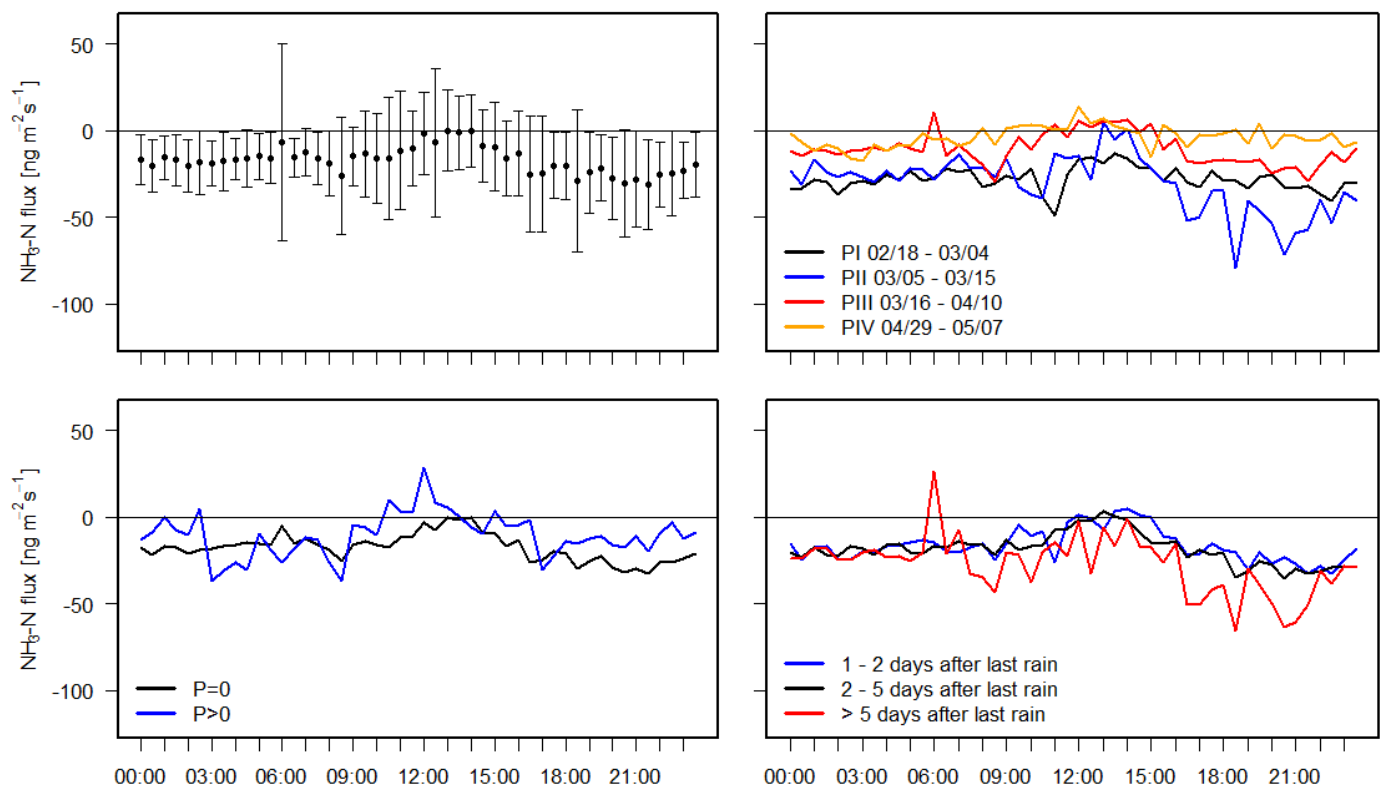

Figure 6. Mean diurnal variation of ammonia fluxes with standard deviation (upper left panel), separated by periods (upper right panel), precipitation (lower left panel), and days after last rain (lower right panel). Dates are given as month/day.

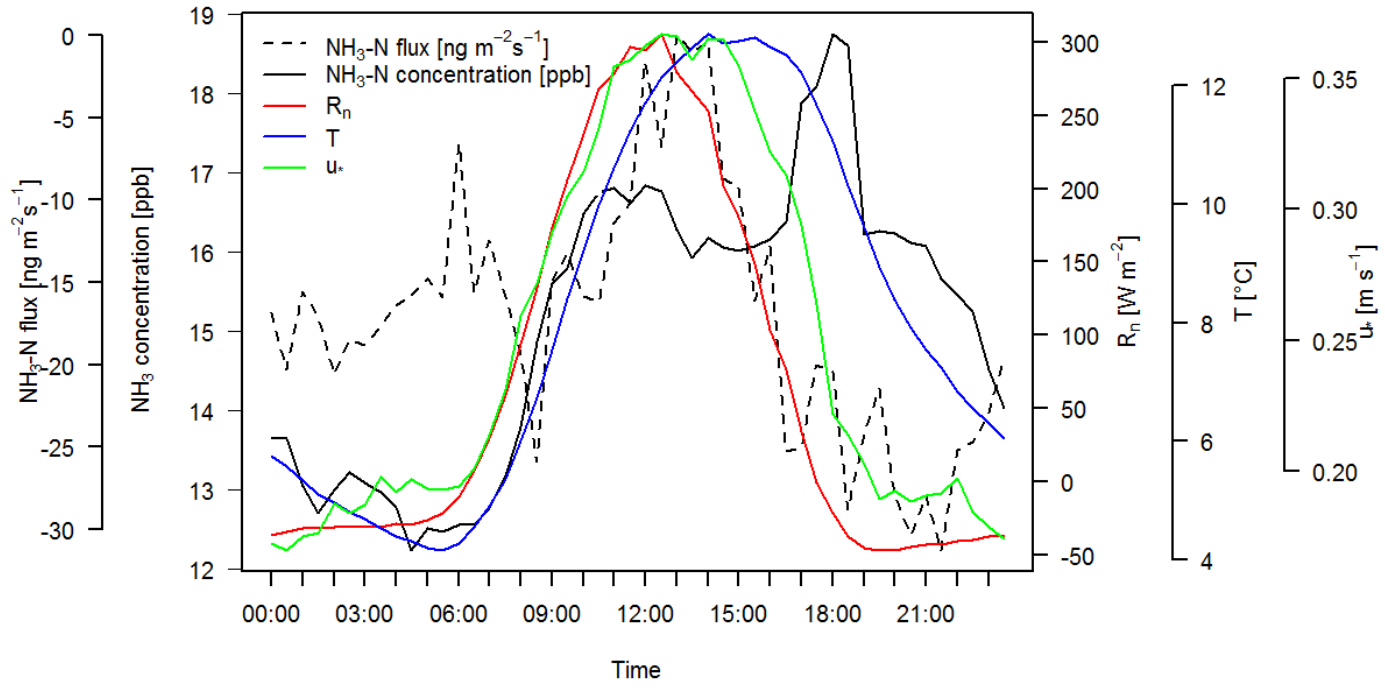

Figure 7. Mean diurnal cycles of ammonia concentration, ammonia flux, net radiation, air temperature, and friction velocity.

Wichink Kruit et al., 2007). An undisturbed peatland site is likely to be a higher ammonia sink than managed grasslands due to a lower nitrogen status and therefore lower ammonia compensation point. However, with the chronically high atmospheric nitrogen loads caused by agriculture over several decades our peatland is presumably not such an efficient sink anymore. With this assumption and the decreasing uptake over the progression of the measurement campaign (box plots in Fig. 3), saturation effects might have played a role in biosphere-atmosphere exchange characteristics. Flechard and Fowler (1998) already showed that peat- land vegetation under its common wet conditions may not necessarily be an "almost perfect sink" as was reported by Duyzer (1994) due to nitrogen saturation effects in heathland plants caused by persistently high ammonia deposition (approx. $13 \mathrm{~kg} \mathrm{Nha}^{-1} \mathrm{yr}^{-1}, 2.5$ times more than in this study) induced by local sources.

Regarding the diurnal flux patterns observed in this study, significantly different exchange characteristics have been reported elsewhere. For example, Horvath et al. (2005) and Wichink Kruit et al. (2007) found highest deposition rates in early morning hours due to dew formation at their grass- 
land sites with decreasing deposition and even emission afterwards through drying leaves and stomatal release. Their finding, i.e., the ecosystem emits only under dry conditions, is contrary to our observations (Figs. 6 and 7).

Regarding the entire campaign, a significant tipping point in ammonia exchange was found on 15 March, when higher deposition rates changed to much lower deposition and bidirectional exchange (cf. Figs. 8 and 11; Sect. 3.3). This tipping point followed 10 days after the onset of spring, occurring on 5 March, as indicated by $\mathrm{CO}_{2}$ uptake shown as significant gross primary productivity in Hurkuck et al. (2016), and was mainly triggered by a significant weather change. A huge pressure drop and daily minimum air temperatures exceeding $5^{\circ} \mathrm{C}$ for the first time in that particular year were recorded. While conditions were dry until 15 March, $25 \mathrm{~mm}$ precipitation was recorded during the following 9 days. Thus, a likely reason for decreasing uptake after 15 March might have been a shift of the stomatal compensation point of the local active peatland vegetation due to higher temperatures as was shown by Milford (2004). Similar to findings in Kim et al. (2011), precipitation after 15 March significantly reduced ammonia concentrations in ambient air while the ratio of wet to dry deposition probably considerably increased.

The tipping point from higher to much lower ecosystem ammonia uptake was also observed in the course of deposition velocities $\left(v_{\mathrm{d}}\right.$; Fig. 8 upper panel, tipping point in this depiction not visible, see also Fig. S3). Mean $v_{\mathrm{d}}$ is defined as the ammonia flux divided by concentration over a given period and is still a valuable indicator to verify dry deposition inferential models such as AUSTAL2000 (Janicke, 2002), even in the case of bidirectional exchange (in the case of emission flux, $v_{\mathrm{d}}$ is negative). In our study mean $v_{\mathrm{d}}$ decreased from approx. $0.5 \mathrm{~cm} \mathrm{~s}^{-1}$ at the beginning of the campaign to approx. $0.2 \mathrm{~cm} \mathrm{~s}^{-1}$ on 15 March and remained relatively constant until the end of the campaign. Compared to $v_{\mathrm{d} \text {,max }}$ $\left(v_{\mathrm{d}, \max }=\left(R_{\mathrm{a}}+R_{\mathrm{b}}\right)^{-1}\right)$ the deposition velocity is, with a few exceptions, always smaller, confirming the plausibility of the data (see Fig. 8 upper panel). The deposition velocity values are significantly lower than those reported by Schrader and Brümmer (2014), who found a median and weighted average of 0.7 and $0.9 \mathrm{~cm} \mathrm{~s}^{-1}$, respectively, for the category "seminatural" $(n=19)$ in their literature review. In that study, single site values of $v_{\mathrm{d}}$ ranged between 0.1 and $1.8 \mathrm{~cm} \mathrm{~s}^{-1}$.

A continuous time series of the canopy compensation point was derived (Fig. 8, lower panel), using the relation by Nemitz et al. (2000) for a single-layer canopy compensation point resistance model $\chi_{\mathrm{c}}=F_{t} \cdot\left(R_{\mathrm{a}}\{z-d\}+R_{\mathrm{b}}\right)+\chi_{\mathrm{a}}\{z-d\}$, where $\chi_{\mathrm{c}}\left(\mu \mathrm{g} \mathrm{m}^{-3}\right)$ is the canopy compensation point at the notional height of trace gas exchange $z_{0}^{\prime}(\mathrm{m}), \chi_{\mathrm{a}}\{z-d\}$ $\left(\mu \mathrm{g} \mathrm{m}^{-3}\right)$ the air $\mathrm{NH}_{3}$ concentration measured at the aerodynamic reference height $z-d(\mathrm{~m}), F_{t}\left(\mu \mathrm{g} \mathrm{m}^{-2} \mathrm{~s}^{-1}\right)$ is the total $\mathrm{NH}_{3}$ flux measured by the EC system, $R_{\mathrm{a}}\{z-d\}\left(\mathrm{s} \mathrm{m}^{-1}\right)$ is the aerodynamic resistance at the reference height, and $R_{\mathrm{b}}\left(\mathrm{s} \mathrm{m}^{-1}\right)$ is the quasi-laminar resistance to $\mathrm{NH}_{3}$ exchange. From this, also the canopy emission potential could be calcu- lated. The results indicate that there appears to be a very large canopy compensation point (compared, for example, to Loubet et al., 2012) that closely follows the air $\mathrm{NH}_{3}$ concentration, which triggers emission events and effectively reduces deposition in the way that it prevents $\mathrm{NH}_{3}$ from depositing at the maximum allowed deposition velocity allowed by turbulence (see Fig. 8 upper panel). The observed tipping point on 15 March is also likely another indicator of increased canopy resistance $\left(R_{\mathrm{c}}\right)$ over time, which effectively reflects the increase of the canopy compensation point, which may be related to both stomatal and non-stomatal influences. As can be seen in Fig. 8 (middle panel) the canopy resistance increases from the beginning and is already on a high level in period II. Note that here $R_{\mathrm{c}}$ is derived from a depositiononly model approach (cf. Sutton et al., 1993). Over a coniferous forest, Wyers and Erisman (1998) described an increase in nocturnal $R_{\mathrm{c}}$ which was interpreted as a consequence of pre-deposited ammonia leading to an alkaline saturation of leaf surfaces. For drying canopy, the same authors also found an increase in $R_{c}$ in a heathland study (Erisman and Wyers, 1993), which is consistent with Walker et al. (2006). Our observations showed that the tipping point occurred in a relatively dry period and also that ammonia uptake remained low during rain events 10 days later. This might indicate that at a certain point ammonia exchange was partly no longer controlled by surface wetness but by the $\mathrm{pH}$ on non-stomatal surfaces. However, stomatal plant physiological effects in the form of the seasonal onset of $\mathrm{CO}_{2}$ uptake as mentioned above were likely caused by the change in weather and therefore probably be the main reason for the tipping point.

The statistical significance of the ammonia flux dependency on meteorological variables when classified into different ranges of values was checked by means of a KruskalWallis test (Table 2, see also Table S1 in the Supplement for deposition velocity, canopy resistance, canopy compensation point, and emission potential). The null hypothesis of identical population was rejected in all cases when the $p$ value was below the commonly used significance level of $\alpha=0.05$. A post hoc test confirmed that the distributions in all groups, except for " $1-2$ days" and "2-5 days" in the category "days after last rain", were significantly different. Thus, all criteria, i.e., the biophysical factors air temperature, precipitation, surface wetness, and radiation, had a statistically significant influence on ammonia exchange. However, fluxes were not well correlated with air temperature, radiation, or concentration $\left(R^{2}<0.1\right)$ when using simple regression analysis. Milford et al. (2001) reported that these variables usually regulate the ammonia exchange but could not find a good correlation between flux and temperature or radiation either because of many nonlinear interrelations (cf. Milford, 2004; Yamulki et al., 1996). This can be confirmed by visually inspecting the diurnal cycles shown in Fig. 7. The course of ammonia fluxes is more closely coupled to net radiation and $u_{*}$, whereas peaks in concentration, rather than forming a bimodal pattern, follow the shape of air temperature with 


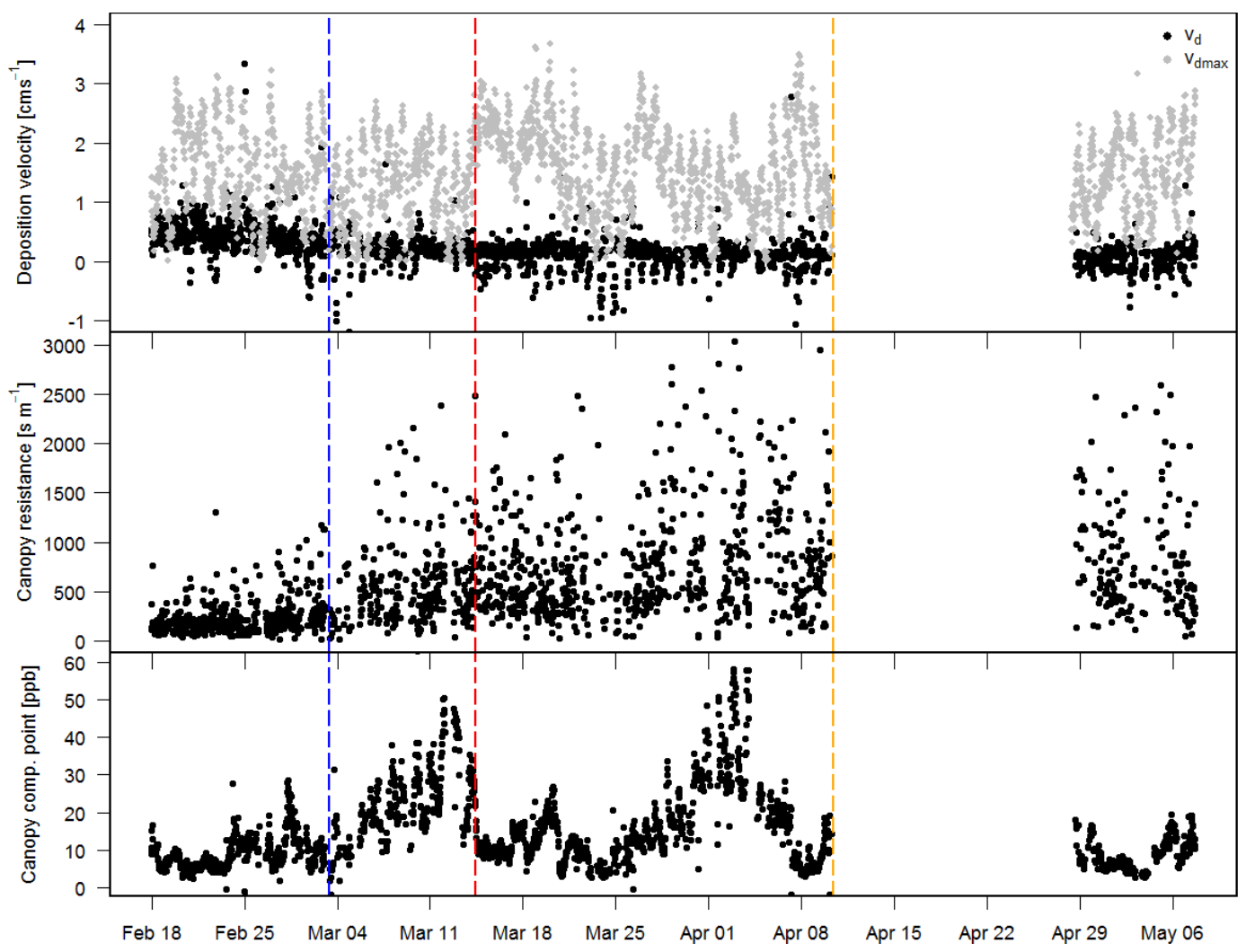

Figure 8. Upper panel: deposition velocity; negative values indicate emission and maximum deposition velocity. Middle panel: canopy resistance; negative values are not shown, as they are not defined in the resistance framework and mostly correspond to phases of emission. Lower panel: canopy compensation point derived from measured data. Note that the upper and middle panels are based on a one-layer deposition only and the lower panel to a one-layer canopy compensation point framework (cf. Sutton et al., 1993).

a 2-3 h lag. Furthermore, solubility of ammonia is related to temperature, which in turn drives the opening of stomata (Fowler et al., 1998), although the response of radiation is much stronger and the temperature effect on stomatal conductance is often confounded by the stronger vapor pressure deficit effects. With increasing temperature ammonia is less dissociated in the available water reservoirs and the plants are able to easier release it to the atmosphere.

Radiation and temperature are also driving local turbulence, i.e., $u_{*}$, which appears also to be a controlling factor for both ammonia concentration and fluxes (Fig. 9). While concentrations were lowest under low turbulence, even when analyzed for single periods, maxima were observed in the 0.1 to $0.2 \mathrm{~m} \mathrm{~s}^{-1}$ class with slightly decreasing values under increasing turbulence, which is a natural phenomenon due to better mixing and transport in the boundary layer, whereas low concentrations under low turbulence at night are likely an artefact of the local fertilizer management that is usually applied during the day. Highest uptake fluxes, however, were found under low $u_{*}$, whereas lowest uptake was found under high $u_{*}$. This is confirmed by separating day and nighttime data with highest uptake of ammonia clearly occurring during the night (left and middle panel of Fig. 9).
The same patterns were found when plotting $u_{*}$ vs. normalized fluxes, e.g., $v_{\mathrm{d}}$ (not shown). Decreasing uptake with increasing $u_{*}$ is rather an unusual finding and could be indicating that the control of turbulence is significantly masked by the strong influence of plant physiological regulation (vapour pressure deficit response of stomata) and agricultural practices at our study site with co-occurring gradual ammonia saturation of the leaf surface. However, it could be a consequence of a stomatal or ground compensation point which follows the daily surface temperature course. The temperature itself increases with increasing $u_{*}$, also during nights with clear sky, therewith the compensation point increases, which leads to less uptake and less deposition, respectively. Further, at low turbulence local transport from nearby fields and farms into the peatland occurs, while at high turbulence a high proportion is going directly from the sources into longdistance transport. In daytime this is mirrored by the flux; thus it seems like the influence of $u_{*}$ on the ammonia flux is small compared to concentration. At nighttime there is no tendency except a generally higher flux compared to daytime, which may be an effect of wet surfaces rather than any turbulence effect. It has been reported - even for agricultural sites - that medium to high turbulence favors the magnitude 
Table 2. Data classification and results of Kruskal-Wallis test on the $\mathrm{NH}_{3}$ flux; the null hypothesis of identical population is rejected when the $p$ value is below the significance level of $\alpha=0.05$. The post hoc test confirms that the distributions in all groups are significantly different; if not, the equal groups are listed (see Sect. 3.2 for further details and Table S1 for tests on other variables).

\begin{tabular}{|c|c|c|c|c|c|}
\hline \multirow[t]{2}{*}{ Meteorological variable } & \multicolumn{3}{|c|}{ Groups } & \multirow[t]{2}{*}{$p$ value } & \multirow[t]{2}{*}{ Post hoc } \\
\hline & 1 & 2 & 3 & & \\
\hline Air temperature & $<5^{\circ} \mathrm{C}$ & $5-10^{\circ} \mathrm{C}$ & $>10^{\circ} \mathrm{C}$ & $<0.001$ & All differ \\
\hline Precipitation & $0 \mathrm{~mm}$ & $>0 \mathrm{~mm}$ & & $<0.001$ & All differ \\
\hline Days after last rain & $1-2$ days & $2-5$ days & $>5$ days & $<0.001$ & $1=2$ \\
\hline Net radiation & $<0 \mathrm{~W} \mathrm{~m}^{-2}$ & $0-150 \mathrm{~W} \mathrm{~m}^{-2}$ & $>150 \mathrm{~W} \mathrm{~m}^{-2}$ & $<0.001$ & All differ \\
\hline
\end{tabular}

of exchange fluxes, regardless of direction, i.e., emission or deposition (cf. Brümmer et al., 2013).

The interdependency of the ammonia flux and concentrations is shown in Fig. 10. We separated emission from deposition periods and bin-averaged the concentration data (for an extract without bin-averaging see Fig. S2). Our observations are consistent with Milford (2004) who also found both increasing emission and deposition under elevated concentration, also when separating by wind direction (data not shown). It remains a matter of speculation whether the flux controls the concentration or vice versa as the relationship is highly controlled by plant nitrogen status and at least to some extent by biometeorological variables as mentioned above. However, Milford's (2004) statement that the concentration may still determine the flux during deposition periods, whereas during emission periods it may be the ammonia flux itself that is controlling the concentration, is also likely be applicable for our site during deposition periods. In emission periods, a coincidence of flux drivers and high concentration levels, which were high due to advection from the local sources, is the more realistic reason for the relationship in Fig. 10 (right panel). The nearest agricultural ammonia point source was $1.5 \mathrm{~km}$ away from the tower. With a measurement height of $2.5 \mathrm{~m}$ none of the sources were located within the flux footprint, and thus we can largely exclude effects from flux heterogeneity such as a direct contribution of the sources to the measured vertical fluxes. However, there might be still large-scale transport processes as outlined in a study by Mohr et al. (2015) that influence ammonia concentrations at the site. What is needed at this point is not just an observation on one field and one ecosystem, but a landscapescale or regional-scale model of emission, dispersion, chemistry, exchange, and deposition that makes it possible to work on this question interactively.

\subsection{Measured vs. modeled fluxes and cumulative exchange}

The comparison of measured and modeled daily mean and cumulative half-hourly ammonia fluxes is given in Figs. 10 and 11 (for 1 week with half-hourly values see Fig. S4). We found a considerable mismatch between modeled and mea- sured fluxes with the latter showing higher uptake in period I and lower uptake in period III than model outputs. In contrast, during periods II and IV measured and simulated fluxes run fairly parallel, with the exception of a short period of overestimated deposition during last week of March, indicating that, on average, during these times the model is able to reproduce the measured fluxes well. The interdependency of modeled ammonia fluxes and measured concentrations is very similar to the measured ones except that the model does not exhibit any emission and the fluxes are generally lower with increasing concentrations (Fig. 10). We do not see the larger measured deposition fluxes during periods I and II as being indicative of faulty measurements. Instead, we suspect that under the local pollution climate during the measurement period, the model predicts a too large non-stomatal resistance $\left(R_{\mathrm{W}}\right)$. The Massad et al. (2010) parameterization uses a so-called acid to ammonia ratio (AAR), i.e., the molar ratio of the sum of $\mathrm{HNO}_{3}, \mathrm{SO}_{2}$, and $\mathrm{HCl}$ concentrations to the $\mathrm{NH}_{3}$ concentration, to scale the minimum allowed $R_{\mathrm{w}}$ in the model. The very low AAR ( 0.07 to 0.11 ) measured at the peatland site increases the baseline $($ acid ratio $=1)$ minimum $R_{\mathrm{w}}$ of $31.5 \mathrm{~s} \mathrm{~m}^{-1}$ roughly 9 to 14 fold. A comparison with non-stomatal resistances inferred from nighttime measured fluxes and modeled $R_{\mathrm{a}}(z-d)$ and $R_{\mathrm{b}}$ (cf. Wichink Kruit et al., 2010) reveals that this is too large for periods I and II (not shown here); however, in periods III and IV, when temperatures rise and thermodynamic equilibria are shifted towards ammonia in the gas phase - increasing apparent $R_{\mathrm{W}}$ and decreasing deposition on the external leaf surfaces - the model is able to reproduce the measured $R_{\mathrm{W}}$ well. Furthermore, $\mathrm{HNO}_{3}, \mathrm{SO}_{2}$, and $\mathrm{HCl}$ concentrations were only measured on a monthly basis using DELTA denuders, thus introducing some uncertainty to the estimated acid ratio and therefore modeled $R_{\mathrm{w}}$. A detailed investigation on $R_{\mathrm{w}}$ parameterizations can be found in Schrader et al. (2016).

Regarding the canopy compensation point (Fig. 8, lower panel) it must be considered that in a unidirectional framework, this high canopy compensation point increases the effective canopy resistance $R_{\mathrm{c}}$ (Fig. 8, middle panel), and it appears to have a much larger influence on the observed fluxes than the atmospheric resistances. The constant (stomatal) emission potential from the Massad et al. (2010) model 

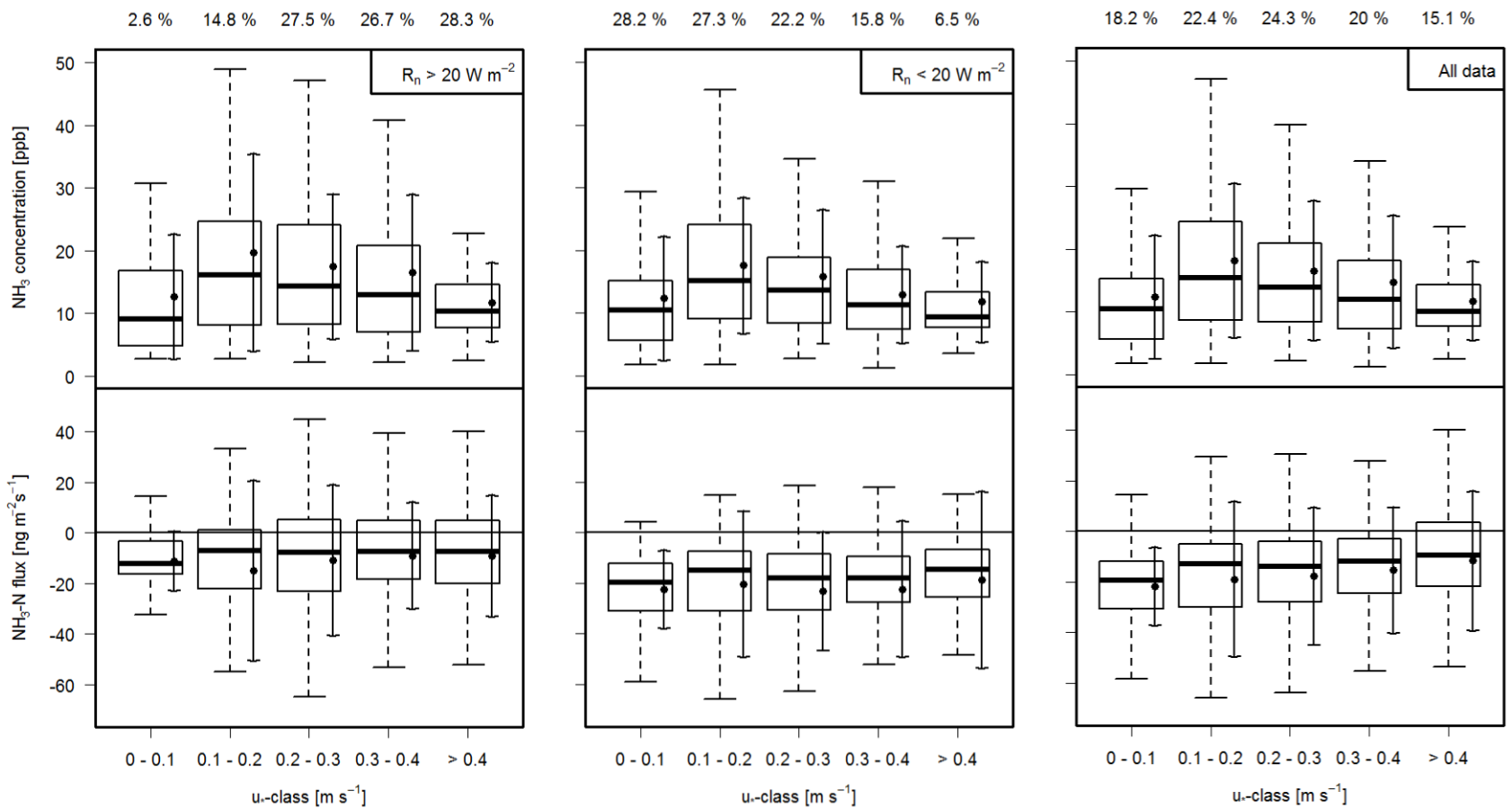

Figure 9. Dependency of ammonia concentrations and fluxes on $u_{*}$, with panels from left to right showing daytime $\left(R_{\mathrm{n}}>20 \mathrm{~W} \mathrm{~m}^{-2}\right)$, nighttime $\left(R_{\mathrm{n}}<20 \mathrm{~W} \mathrm{~m}^{-2}\right)$, and all data, respectively. Bold horizontal lines in box plots show the median, fine horizontal lines indicate lower and upper quartile values, whiskers represent 1.5 times the interquartile range, and dots with arrows indicate the mean and standard deviation. Values in upper row specify percentages of data in the respective $u_{*}$ category given below.
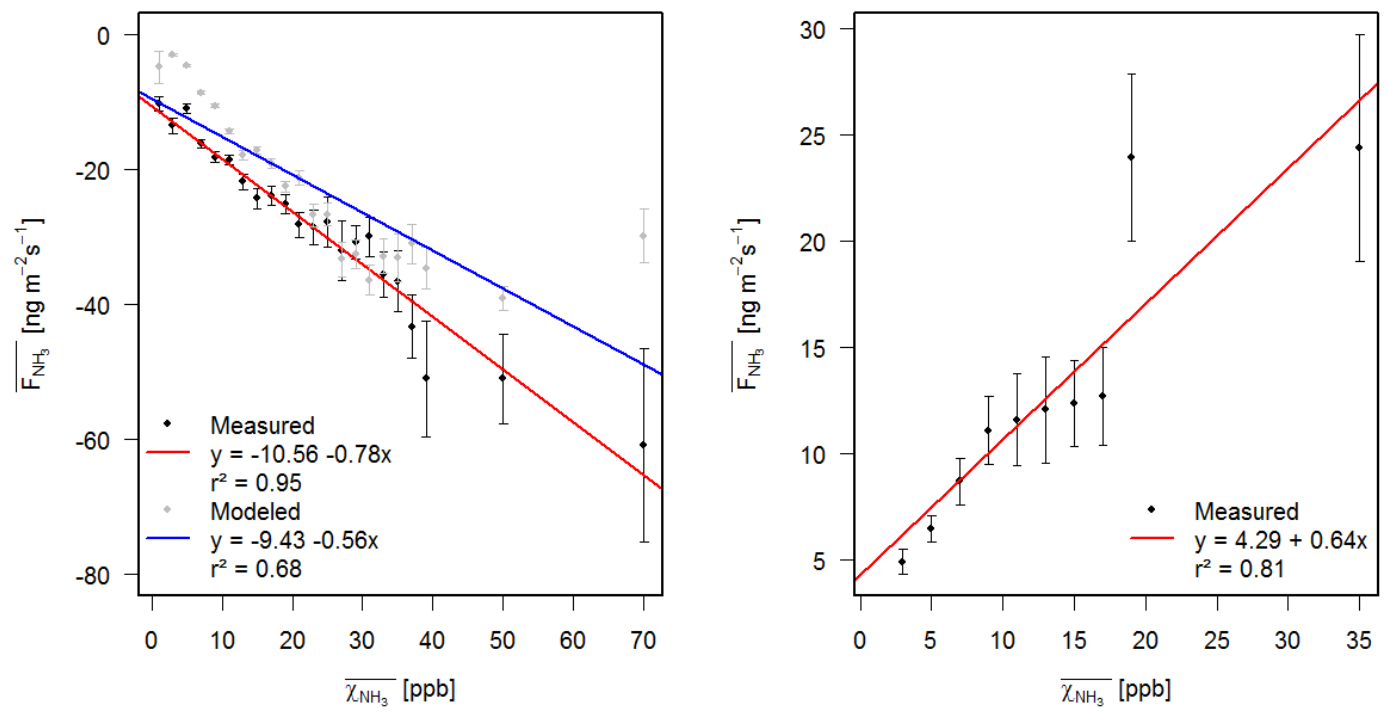

Figure 10. Dependency of $\mathrm{NH}_{3}$ fluxes, measured and modeled, on bin-averaged $\mathrm{NH}_{3}$ concentrations (bin sizes are 2 ppb for concentrations $<40$ and $<20 \mathrm{ppb}$ in the left and right panel, respectively; for concentrations $>40 \mathrm{ppb}$ bin sizes are $20 \mathrm{ppb}$ ) during deposition (100\% of the modeled and $84 \%$ of the measured data, left panel) and emission periods (16\% of the measured data, right panel); error bars indicate standard error.

is much lower than the observed canopy emission potentials, and the stomatal compensation point is only a function of temperature, not of the ambient $\mathrm{NH}_{3}$ concentration, which may be an indicator that, at this site, there is another, am- bient, concentration-dependent bidirectional pathway that is not being modeled (e.g., wet surfaces; as described, for example, by Burkhardt et al. (2009) for the case of leaf wetness). 


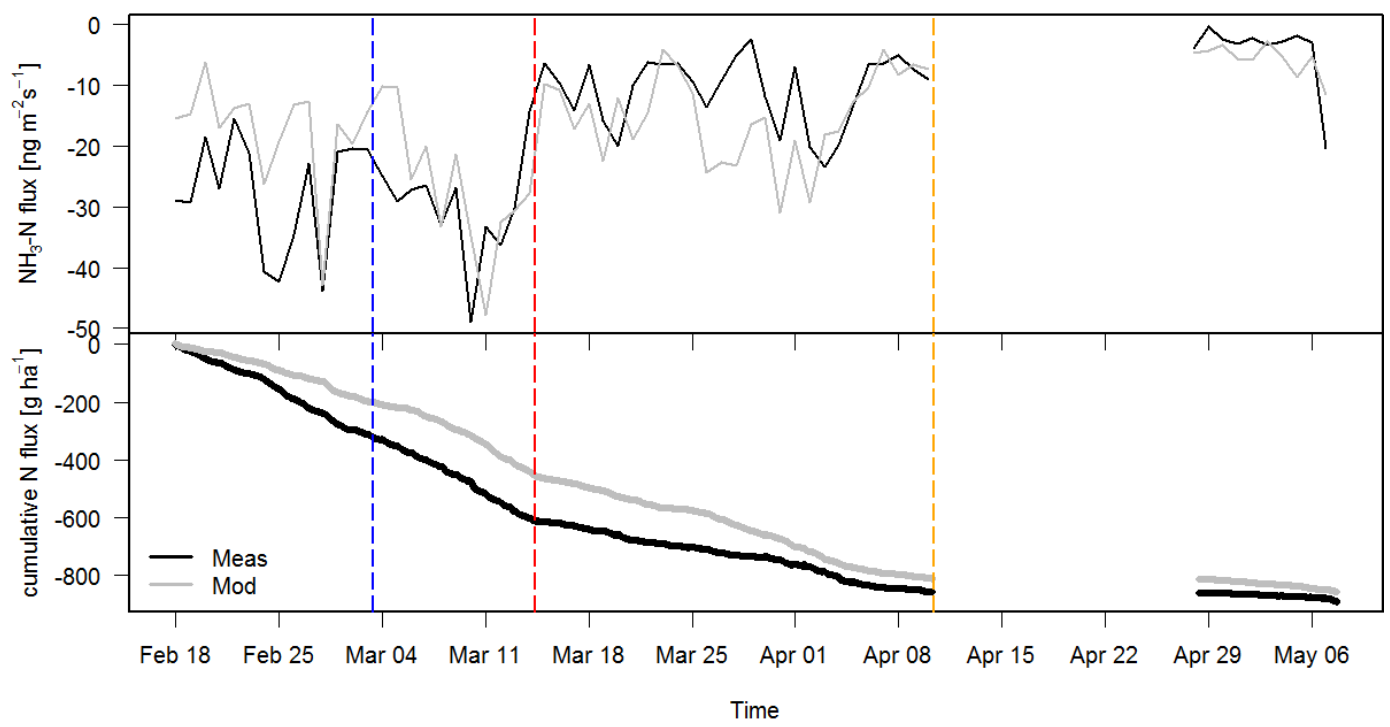

Figure 11. Comparison of measured and modeled daily mean $\mathrm{NH}_{3}$ fluxes (upper panel) and cumulative $\mathrm{NH}_{3}$ flux (lower panel) based on half-hourly data during the measurement campaign. Vertical lines indicate the start of periods II, III, and IV as listed in Table 1.

The cumulative exchange after approx. 9 weeks of observation resulted in total deposition of 911 and $857 \mathrm{~g} \mathrm{NH}_{3}-$ $\mathrm{Nha}^{-1}$ for measurements and model output, respectively, thus matching relatively well over a longer period despite considerable deviation in periods I and II. Hurkuck et al. (2014) estimated annual ammonia deposition of $8.5 \mathrm{~kg} \mathrm{Nha}^{-1}$ at the same study site using denuder filter systems in combination with inferential modeling. They found considerable seasonal variability and also accounted agricultural practices in the surrounding area as the main driver for ammonia exchange variability. Extrapolating our measurement-based campaign total time proportionally to an entire year results in a net deposition estimate of approx. $5.3 \mathrm{~kg} \mathrm{NH}_{3}-\mathrm{Nha}^{-1}$. Reasons for the mismatch might be the fact that our measurements are based on a much higher time resolution, leading to a more accurate representation of emission components in the net signal of the EC fluxes. Additionally, $R_{\mathrm{W}}$ is based on a much more complex parameterization in Massad et al. (2010), including AAR and a correction for temperature and leaf area index, than those methods used in Hurkuck et al. (2014). However, even with an approx. $3.2 \mathrm{~kg} \mathrm{Nha}^{-1} \mathrm{yr}^{-1}$ lower ammonia deposition, our study site remains a substantial total nitrogen sink. Adding the numbers presented in Hurkuck et al. (2014), i.e., another $2.4 \mathrm{~kg} \mathrm{Nha}^{-1} \mathrm{yr}^{-1}$ dry deposition of $\mathrm{HONO}, \mathrm{HNO}_{3}$, and $\mathrm{NH}_{4} \mathrm{NO}_{3}$ aerosols as well as $14 \mathrm{~kg} \mathrm{Nha}^{-1} \mathrm{yr}^{-1}$ as wet deposition, total nitrogen deposition results in approx. 21.7 $\mathrm{kg} \mathrm{N} \mathrm{ha}^{-1} \mathrm{yr}^{-1}$, thereby exceeding the ecosystem-specific critical load of $5 \mathrm{~kg}, \mathrm{~N} \mathrm{ha}^{-1} \mathrm{yr}^{-1}$ more than four times (cf. Bobbink et al., 2010; UNECE, 2004).

\section{Conclusions}

EC flux measurements of ammonia using a QCL in combination with an "inertial inlet box" were conducted at a peatland site in an agricultural landscape. This methodology has high potential for (1) establishment in long-term observation networks with the aim to improve nitrogen budgets and transfer calculations at local and regional scale as well as (2) providing deeper insight into the mechanisms of ammonia transfer and the ecosystems' responses to ammonia loads in the atmosphere by offering continuous flux observations at unprecedentedly high temporal resolution. In the present study, we interpret changing diurnal patterns of ammonia concentration and fluxes as well as a tipping point followed by decreasing deposition velocities and increasing canopy resistance, as a sign of non-stomatal leaf surface $\mathrm{NH}_{3}$ saturation in response to elevated $\mathrm{NH}_{3}$ from agricultural activities (i.e., manure spreading), as well as delayed plant physiological effects after the onset of the growing season. Temperature, radiation, and surface wetness were identified to partially regulate ammonia exchange at the site; however, the seasonal concentration pattern was clearly dominated by emissions from agricultural practices in the surrounding area. Overestimations of non-stomatal resistances due to low acid to ammonia ratios were assumed to be responsible for deviations between modeled and measured flux estimates. On a total cumulative campaign basis the estimated net $\mathrm{NH}_{3}$ exchange differed only by $6 \%$ between the model and independent flux measurements. Lower QCL-based deposition values than those of using denuder systems were likely due to a better representation of the emission component in the net signal of EC fluxes as well as better adapted sitespecific model parameters, particularly $R_{\mathrm{w}}$. Further research 
is needed on long-term stability of the QCL system and on avoidance of unintended reactions of ammonia within the inlet and sample tube.

\section{Data availability}

Data will be archived and are available from the corresponding author on request.

\section{The Supplement related to this article is available online at doi:10.5194/acp-16-11283-2016-supplement.}

Acknowledgements. Funding for this study from the German Federal Ministry of Education and Research (BMBF) within the framework of the Junior Research Group NITROSPHERE under support code FKZ 01LN1308A is greatly acknowledged. We thank Jeremy Smith, Jean-Pierre Delorme, as well as Ute Tambor, Andrea Niemeyer, and Daniel Ziehe for excellent technical support and conducting laboratory analyses of denuder and filter samples, respectively.

Edited by: L. Zhang

Reviewed by: two anonymous referees

\section{References}

Ammann, C., Brunner, A., Spirig, C., and Neftel, A.: Technical note: Water vapour concentration and flux measurements with PTR-MS, Atmos. Chem. Phys., 6, 4643-4651, doi:10.5194/acp6-4643-2006, 2006.

Asman, W. A. H., Sutton, M. A., and Schjørring, J. K.: Ammonia: emission, atmospheric transport and deposition, New Phytol., 139, 27-48, 1998.

Bobbink, R., Hicks, K., Galloway, J., Spranger, T., Alkemade, R., Ashmore, M., Bustamante, M., Cinderby, S., Davidson, E., Dentener, F., Emmett, B.A., Erisman, J. W., Fenn, M., Gilliam, F. S., Nordin, A., Pardo, L., and de Vries, W.: Global assessment of nitrogen deposition effects on terrestrial plant diversity: a synthesis, Ecol. Appl. 20, 30-59, 2010.

Brümmer, C., Marx, O., Kutsch, W., Ammann, C., Wolff, V., Flechard, C. R., and Freibauer, A.: Fluxes of total reactive atmospheric nitrogen $(\Sigma \mathrm{Nr})$ using eddy covariance above arable land, Tellus B, 65, 19770, doi:10.3402/tellusb.v65i0.19770, 2013.

Burkhardt, J., Flechard, C. R., Gresens, F., Mattsson, M., Jongejan, P. A. C., Erisman, J. W., Weidinger, T., Meszaros, R., Nemitz, E., and Sutton, M. A.: Modelling the dynamic chemical interactions of atmospheric ammonia with leaf surface wetness in a managed grassland canopy, Biogeosciences, 6, 67-84, doi:10.5194/bg-667-2009, 2009.

Dämmgen, U. and Zimmerling, R.: Vertical Fluxes of Air-Borne Acidifying and Eutrophying Species in the Schorfheide Nature Reserve in Brandenburg, Germany, J. Appl. Bot., 76, 190-202, 2002.
Dämmgen, U., Thöni, L., Seitler, E., Lumpp, R., Bullinger, M., and Gilke, K.: Performance characteristics for the determination of ammonia concentrations in ambient air - Part 2: Passive sampler measurements, Gefahrstoffe Reinhaltung der Luft, 70, 367-372, 2010.

Denmead, O. T., Macdonald, B. C. T., Bryant, G., Naylor, T., Wilson, S., Griffith, D. W. T., Wang, W. J., Salter, B., White, I., and Moody, P. W.: Emissions of methane and nitrous oxide from Australian sugarcane soils, Agr. Forest Meteorol., 748-756, 2010.

Duyzer, J.: Dry deposition of ammonia and ammonium aerosols over heathland, J. Geophys. Res., 99, 18-757, 1994.

Ellis, R. A., Murphy, J. G., Pattey, E., van Haarlem, R., O'Brien, J. M., and Herndon, S. C.: Characterizing a Quantum Cascade Tunable Infrared Laser Differential Absorption Spectrometer (QCTILDAS) for measurements of atmospheric ammonia, Atmos. Meas. Tech., 3, 397-406, doi:10.5194/amt-3-397-2010, 2010.

Emberson, L. D., Wieser, G., and Ashmore, M. R.: Modelling of stomatal conductance and ozone flux of Norway spruce: comparison with field data, Environ. Pollut., 109, 393-402, 2000.

Erisman, J. W. and Wyers, G. P.: Continuous measurements of surface exchange of $\mathrm{SO}_{2}$ and $\mathrm{NH}_{3}$; Implications for their possible interaction in the deposition process, Atmos. Environ. A.-Gen., 27, 1937-1949, 1993.

Erisman, J. W., Sutton, M. A., Galloway, J., Klimont, Z., and Winiwarter, W.: How a century of ammonia synthesis changed the world, Nat. Geosci., 1, 636-639, 2008.

Erisman, J. W., Galloway, J. N., Seitzinger, S., Bleeker, A., Dise, N. B., Petrescu, A. M. R., Leach, A. M., and de Vries, W.: Consequences of human modification of the global nitrogen cycle, Philos. T. R. Soc. B, 368, 20130116, doi:10.1098/rstb.2013.0116, 2013.

Falge, E., Baldocchi, D., Olson, R., Anthoni, P., Aubinet, M., Bernhofer, C., Burba, G., Ceulemans, R., Clement, R., Dolman, H., Granier, A., Gross, P., Grünwald, T., Hollinger, D., Jensen, N.O., Katul, G., Keronen, P., Kowalski, A., Lai, C. T., Law, B. E., Meyers, T., Moncrieff, J., Moors, E., Munger, J. W., Pilegaard, K., Rannik, Ü., Rebmann, C., Suyker, A., Tenhunen, J., Tu, K., Verma, S., Vesala, T., Wilson, K., and Wofsy, S.: Gap filling strategies for defensible annual sums of net ecosystem exchange, Agr. Forest Meteorol., 107, 43-69, 2001.

Famulari, D., Fowler, D., Hargreaves, K., Milford, C., Nemitz, E., Sutton, M. A., and Weston, K.: Measuring eddy covariance fluxes of ammonia using tunable diode laser absorption spectroscopy, Water, Air Soil Pollut. Focus, 4, 151-158, 2004.

Ferrara, R. M., Loubet, B., Di Tommasi, P., Bertolini, T., Magliulo, V., Cellier, P., Eugster, W., and Rana, G.: Eddy covariance measurement of ammonia fluxes: Comparison of high frequency correction methodologies, Agr. Forest Meteorol., 158-159, 3042, 2012.

Ferrara, R. M., Carozzi, M., Di Tommasi, P., Nelson, D. D., Fratini, G., Bertolini, T., Magliulo, V., Acutis, M., and Rana, G.: Dynamics of ammonia volatilisation measured by eddy covariance during slurry spreading in north Italy, Agr. Ecosyst. Environ., 219, 1-13, 2016.

Finkelstein, P. L. and Sims, P.F .: Sampling error in eddy correlation flux measurements, J. Geophys. Res., 106, 3503-3509, 2001.

Flechard, C. R. and Fowler, D.: Atmospheric ammonia at a moorland site, II: Long-term surface-atmosphere micrometeorological flux measurements, Roy. Meteorol. Soc., 124, 759-791, 1998. 
Flechard, C. R., Fowler, D., Sutton, M. A., and Cape, J. N.: A dynamic chemical model of bi-directional ammonia exchange between semi-natural vegetation and the atmosphere, Q. J. Roy. Meteorol. Soc., 125, 2611-2641, 1999.

Flechard, C. R., Nemitz, E., Smith, R. I., Fowler, D., Vermeulen, A. T., Bleeker, A., Erisman, J. W., Simpson, D., Zhang, L., Tang, Y. S., and Sutton, M. A.: Dry deposition of reactive nitrogen to European ecosystems: a comparison of inferential models across the NitroEurope network, Atmos. Chem. Phys., 11, 2703-2728, doi:10.5194/acp-11-2703-2011, 2011.

Flechard, C. R., Massad, R.-S., Loubet, B., Personne, E., Simpson, D., Bash, J. O., Cooter, E. J., Nemitz, E., and Sutton, M. A.: Advances in understanding, models and parameterizations of biosphere-atmosphere ammonia exchange, Biogeosciences, 10, 5183-5225, doi:10.5194/bg-10-5183-2013, 2013.

Fowler, D., Flechard, C. R., Sutton, M. A., and Storeton-west, R. L.: Long term measurements of the land-atmosphere exchange of ammonia over moorland, Atmos. Environ., 32, 453-459, 1998.

Galloway, J. N., Aber, J. D., Erisman, J. W., Seitzinger, S. P., Howarth, R. W., Cowling, E. B., and Cosby, B. J.: The nitrogen cascade, BioScience, 53, 341-356, 2003.

German Weather Service: Deutsche Wetterdienst, http://www.dwd. de/DE/leistungen/klimadatendeutschland/langj_mittelwerte. html;jsessionid=3A217F56F6F162BCBB87547E9FECAB9F. live21062? $\mathrm{nn}=495662 \& 1$ lsbId=343278, last access: 16 December 2015.

Horváth, L., Asztalos, M., Führer, E., Mészáros, R., and Weidinger, T.: Measurement of ammonia exchange over grassland in the Hungarian Great Plain, Agr. Forest Meteorol., 130, 282-298, 2005.

Hurkuck, M., Brümmer, C., Mohr, K., Grünhage, L., Flessa, H., and Kutsch, W. L.: Determination of atmospheric nitrogen deposition to a semi-natural peat bog site in an intensively managed agricultural landscape, Atmos. Environ., 97, 296-309, 2014.

Hurkuck, M., Brümmer, C., and Kutsch, W.L.: Near-neutral carbon dioxide balance at a semi-natural, temperate bog ecosystem, J. Geophys. Res.-Biogeo., 121, 370-384, doi:10.1002/2015JG003195, 2016.

Ibrom, A., Dellwik, E., Jensen, N. O., Flyvbjerg, H., and Pilegaard, K.: Strong low-pass filtering effects on water vapour flux measurements with closed-path eddy correlation systems, Agr. Forest Meteorol., 147, 140-156, 2007.

Janicke, L.: Lagrangian dispersion modelling, Landbauforsch Völkenrode, 235, 37-41, 2002.

Kim, J.-S., Bais, A. L., Kang, S.-H., Lee, J., and Park, K.: A semicontinuous measurement of gaseous ammonia and particulate ammonium concentrations in PM2.5 in the ambient atmosphere, J. Atmos. Chem., 68, 251-263, 2011.

Kolle, O. and Rebmann, C.: EddySoft Documentation of a Software Package to Acquire and Process Eddy Covariance Data, MPIBGC, 2009.

Kroon, P. S., Schuitmaker, A., Jonker, H. J. J., Tummers, M. J., Hensen, A., and Bosveld, F. C.: An evaluation by laser Doppler anemometry of the correction algorithm based on Kaimal cospectra for high frequency losses of EC flux measurements of $\mathrm{CH}_{4}$ and $\mathrm{N}_{2} \mathrm{O}$, Agr. Forest Meteorol., 150, 794-805, 2010.

Krupa, S. V.: Effects of atmospheric ammonia $\left(\mathrm{NH}_{3}\right)$ on terrestrial vegetation: a review, Environ. Pollut., 124, 179-221, 2003.
Langford, B., Acton, W., Ammann, C., Valach, A., and Nemitz, E.: Eddy-covariance data with low signal-to-noise ratio: time-lag determination, uncertainties and limit of detection, Atmos. Meas. Tech., 8, 4197-4213, doi:10.5194/amt-8-4197-2015, 2015.

Loubet, B., Decuq, C., Personne, E., Massad, R. S., Flechard, C., Fanucci, O., Mascher, N., Gueudet, J.-C., Masson, S., Durand, B., Genermont, S., Fauvel, Y., and Cellier, P.: Investigating the stomatal, cuticular and soil ammonia fluxes over a growing tritical crop under high acidic loads, Biogeosciences, 9, 1537-1552, doi:10.5194/bg-9-1537-2012, 2012.

Marx, O., Brümmer, C., Ammann, C., Wolff, V., and Freibauer, A.: TRANC - a novel fast-response converter to measure total reactive atmospheric nitrogen, Atmos. Meas. Tech., 5, 1045-1057, doi:10.5194/amt-5-1045-2012, 2012.

Massad, R.-S., Nemitz, E., and Sutton, M. A.: Review and parameterisation of bi-directional ammonia exchange between vegetation and the atmosphere, Atmos. Chem. Phys., 10, 10359-10386, doi:10.5194/acp-10-10359-2010, 2010.

Massman, W. J. and Ibrom, A.: Attenuation of concentration fluctuations of water vapor and other trace gases in turbulent tube flow, Atmos. Chem. Phys., 8, 6245-6259, doi:10.5194/acp-86245-2008, 2008.

Mauder, M. and Foken, T.: Impact of post-field data processing on eddy covariance flux estimates and energy balance closure, Meteorol. Z., 15, 597-609, 2006.

McManus, J. B., Shorter, J. H., Nelson, D. D., Zahniser, M. S., Glenn, D. E., and McGovern, R. M.: Pulsed quantum cascade laser instrument with compact design for rapid, high sensitivity measurements of trace gases in air, Appl. Phys. B, 92, 387-392, 2008.

Merbold, L., Eugster, W., Stieger, J., Zahniser, M., Nelson, D. D., and Buchmann, N.: Greenhouse gas budget $\left(\mathrm{CO}_{2}, \mathrm{CH}_{4}\right.$ and $\mathrm{N}_{2} \mathrm{O}$ ) of intensively managed grassland following restoration, Glob. Change Biol., 20, 1913-1928, 2014.

Milford, C., Hargreaves, K. J., Sutton, M. A., Loubet, B., and Cellier, P.: Fluxes of $\mathrm{NH}_{3}$ and $\mathrm{CO}_{2}$ over upland moorland in the vicinity of agricultural land, J. Geophys. Res.-Atmos., 106, 24169-24181, 2001.

Milford, C.: Dynamics of atmospheric ammonia exchange with intensively-managed grassland, Doctor of Philosophy, The University of Edinburgh, 218 pp., 2004.

Moffat, A. M., Papale, D., Reichstein, M., Hollinger, D. Y., Richardson, A. D., Barr, A. G., Beckstein, C., Braswell, B. H., Churkina, G., Desai, A. R., Falge, E., Gove, J. H., Heimann, M., Hui, D., Jarvis, A. J., Kattge, J., Noormets, A., and Stauch, V. J.: Comprehensive comparison of gap-filling techniques for eddy covariance net carbon fluxes, Agr. Forest Meteorol., 147, 209-232, 2007.

Mohr, K., Suda, J., Kros, H., Brümmer, C., Kutsch, W. L., Hurkuck, M., Woesner, E., and Wesseling, W.: Atmospheric nitrogen inputs and ways of their reduction in raised bogs of northwestern Germany - a case study from an intensively managed agricultural region (in German), Braunschweig: Johann Heinrich von Thünen-Institut, 108 pp., Thünen Report 23, 2015.

Mosquera, J., Hensen, A., van den Bulk, W. C. M., Vermeulen, A. T., and Erisman, J. W.: Long Term $\mathrm{NH}_{3}$ Flux Measurements above Grasslands in The Netherlands, Water Air Soil Pollut.Focus, 1, 203-212, 2001

Neftel, A., Ammann, C., Fischer, C., Spirig, C., Conen, F., Emmenegger, L., Tuzson, B., and Wahlen, S.: $\mathrm{N}_{2} \mathrm{O}$ exchange 
over managed grassland: Application of a quantum cascade laser spectrometer for micrometeorological flux measurements, Agr. Forest Meteorol., 150, 775-785, 2010.

Nemitz, E., Sutton, M. A., Schjoerring, J. K., Husted, S., and Paul Wyers, G.: Resistance modelling of ammonia exchange over oilseed rape, Agr. Forest Meteorol., 105, 405-425, 2000.

Nemitz, E., Hargreaves, K. J., Neftel, A., Loubet, B., Cellier, P., Dorsey, J. R., Flynn, M., Hensen, A., Weidinger, T., Meszaros, R., Horvath, L., Dämmgen, U., Frühauf, C., Löpmeier, F. J., Gallagher, M. W., and Sutton, M. A.: Intercomparison and assessment of turbulent and physiological exchange parameters of grassland, Biogeosciences, 6, 1445-1466, doi:10.5194/bg-61445-2009, 2009.

Norman, M., Spirig, C., Wolff, V., Trebs, I., Flechard, C., Wisthaler, A., Schnitzhofer, R., Hansel, A., and Neftel, A.: Intercomparison of ammonia measurement techniques at an intensively managed grassland site (Oensingen, Switzerland), Atmos. Chem. Phys., 9, 2635-2645, doi:10.5194/acp-9-2635-2009, 2009.

R Core Team: R: A language and environment for statistical computing, R Foundation for Statistical Computing, Vienna, Austria, ISBN 3-900051-07-0, http://www.R-project.org/ (last access: 7 September 2016), 2012.

Rothman, L. S., Gordon, I. E., Barbe, A., Benner, D. C., Bernath, P. F., Birk, M., Boudon, V., Brown, L. R., Campargue, A., Champion, J.-P., Chance, K., Coudert, L. H., Dana, V., Devi, V. M., Fally, S., Flaud, J.-M., Gamache, R. R., Goldman, A., Jacquemart, D., Kleiner, I., Lacome, N., Lafferty, W., Mandin, J.Y., Massie, S. T., Mikhailenko, S. N., Miller, C. E., MoazzenAhmadi, N., Naumenko, O. V., Nikitin, A. V., Orphal, J., Perevalov, V. I., Perrin, A., Predoi-Cross, A., Rinsland, C. P., Rotger, M., Simeckova, M., Smith, M. A. H., Sung, K., Tashkun, S. A., Tennyson, J., Toth, R. A., Vandaele, A. C., Vander Auwera J.: The HITRAN 2008 molecular spectroscopic database, J. Quant. Spectrosc. Ra., 110, 533-572, 2009.

Schrader, F. and Brümmer, C.: Land Use Specific Ammonia Deposition Velocities: a Review of Recent Studies (2004-2013), Water Air Soil Pollut., 225, 1-12, 2014.

Schrader, F., Brümmer, C., Flechard, C. R., Wichink Kruit, R. J., van Zanten, M. C., Richter, U., Hensen, A., and Erisman, J. W.: Nonstomatal exchange in ammonia dry deposition models: Comparison of two state-of-the-art approaches, Atmos. Chem. Phys. Discuss., doi:10.5194/acp-2016-403, in review, 2016.

Sintermann, J., Spirig, C., Jordan, A., Kuhn, U., Ammann, C., and Neftel, A.: Eddy covariance flux measurements of ammonia by high temperature chemical ionisation mass spectrometry, Atmos. Meas. Tech., 4, 599-616, doi:10.5194/amt-4-599-2011, 2011.

Sutton, M. A., Flower, D., and Moncrieff, J. B.: The exchange of atmospheric ammonia with vegetated surfaces. I: Unfertilized vegetation, Q. J. Roy. Meteorol. Soc., 119, 1023-1045, 1993.

Sutton, M. A., Nemitz, E., Milford, C., Fowler, D., Moreno, J., San José, R., Wyers, G. P., Otjes, R. P., Harrison, R., Husted, S., and Schjoerring, J. K.: Micrometeorological measurements of net ammonia fluxes over oilseed rape during two vegetation periods, Agr. Forest Meteorol., 105, 351-369, 2000.

Sutton, M. A., Nemitz, E., Erisman, J. W., Beier, C., Bahl, K. B., Cellier, P., de Vries, W., Cotrufo, F., Skiba, U., Di Marco, C., Jones, S., Laville, P., Soussana, J. F., Loubet, B., Twigg, M., Famulari, D., Whitehead, J., Gallagher, M. W., Neftel, A., Flechard, C. R., Herrmann, B., Calanca, P. L., Schjoerring, J. K., Daemm- gen, U., Horvath, L., Tang, Y. S., Emmett, B. A., Tietema, A., Peñuelas, J., Kesik, M., Brueggemann, N., Pilegaard, K., Vesala, T., Campbell, C.L., Olesen, J. E., Dragosits, U., Theobald, M. R., Levy, P., Mobbs, D. C., Milne, R., Viovy, N., Vuichard, N., Smith, J. U., Smith, P., Bergamaschi, P., Fowler, D., and Reis, S.: Challenges in quantifying biosphere-atmosphere exchange of nitrogen species, Environ. Pollut., 150, 125-139, 2007.

Sutton, M. A., Howard, C. M., Erisman, J. W., Billen, G., Bleeker, A., Grennfelt, P., van Grinsven, H., and Grizzetti, B.: The European Nitrogen Assessment: Sources, Effects, and Policy Perspectives, Cambridge University Press, Cambridge, UK, 2011.

Sutton, M. A., Reis, S., Riddick, S. N., Dragosits, U., Nemitz, E., Theobald, M. R., Tang, Y. S., Braban, C. F., Vieno, M., Dore, A. J., Mitchell, R. F., Wanless, S., Daunt, F., Fowler, D., Blackall, T. D., Milford, C., Flechard, C. R., Loubet, B., Massad, R., Cellier, P., Personne, E., Coheur, P. F., Clarisse, L., Van Damme, M., Ngadi, Y., Clerbaux, C., Skjøth, C. A., Geels, C., Hertel, O., Wichink Kruit, R. J., Pinder, R. W., Bash, J. O., Walker, J. T., Simpson, D., Horváth, L., Misselbrook, T. H., Bleeker, A., Dentener, F., and de Vries, W.: Towards a climate-dependent paradigm of ammonia emission and deposition, Philos. T. R. Soc. B, 368, 20130166, doi:10.1098/rstb.2013.0166, 2013.

Tang, Y. S., Simmons, I., van Dijk, N., Di Marco, C., Nemitz, E., Dämmgen, U., Gilke, K., Djuricic, V., Vidic, S., Gliha, Z., Borovecki, D., Mitosinkova, M., Hanssen, J. E., Uggerud, T. H., Sanz, M. J., Sanz, P., Chorda, J. V., Flechard, C. R., Fauvel, Y., Ferm, M., Perrino, C., and Sutton, M. A.: European scale application of atmospheric reactive nitrogen measurements in a low-cost approach to infer dry deposition fluxes, Agr. Ecosyst. Environ., 133, 183-195, 2009.

UNECE: Manual on Methodologies and Criteria for Modelling and Mapping Critical Loads and Levels and Air Pollution Effects, Risks and Trends, 52/04, Federal Environmental Agency, Germany, 2004.

von Bobrutzki, K., Braban, C. F., Famulari, D., Jones, S. K., Blackall, T., Smith, T. E.L., Blom, M., Coe, H., Gallagher, M., Ghalaieny, M., McGillen, M. R., Percival, C. J., Whitehead, J. D., Ellis, R., Murphy, J., Mohacsi, A., Pogany, A., Junninen, H., Rantanen, S., Sutton, M. A., and Nemitz, E.: Field inter-comparison of eleven atmospheric ammonia measurement techniques, Atmos. Meas. Tech., 3, 9-112, doi:10.5194/amt-3-91-2010, 2010.

Walker, J. T., Robarge, W. P., Wu, Y., and Meyers, T. P.: Measurement of bi-directional ammonia fluxes over soybean using the modified Bowen-ratio technique, Agr. Forest Meteorol., 138, 54 68, 2006.

Warland, J. S., Dias, G. M., and Thurtell, G. W.: A tunable diode laser system for ammonia flux measurements over multiple plots, Environ. Pollut., 114, 215-221, 2001.

Wentworth, G. R., Murphy, J. G., Gregoire, P. K., Cheyne, C. A. L., Tevlin, A. G., and Hems, R.: Soil-atmosphere exchange of ammonia in a non-fertilized grassland: measured emission potentials and inferred fluxes, Biogeosciences, 11, 5675-5686, doi:10.5194/bg-11-5675-2014, 2014.

Wesely, M.L.: Parameterization of surface resistances to gaseous dry deposition in regional-scale numerical models, Atmos. Environ., 23, 1293-1304, 1989.

Wichink Kruit, R. J., van Pul, W. A. J., Otjes, R. P., Hofschreuder, P., Jacobs, A. F. G., and Holtslag, A. A. M.: Ammonia fluxes and derived canopy compensation points over non-fertilized agricul- 
tural grassland in The Netherlands using the new gradient ammonia - high accuracy - monitor (GRAHAM), Atmos. Environ., 41, 1275-1287, 2007.

Wichink Kruit, R. J., Van Pul, W. A. J., Sauter, F. J., Van den Broek, M., Nemitz, E., Sutton, M. A., Krol, M., and Holtslag, A. A. M.: Modeling the surface-atmosphere exchange of ammonia, Atmos. Environ., 44, 945-957, 2010.

Wolff, V., Trebs, I., Ammann, C., and Meixner, F. X.: Aerodynamic gradient measurements of the $\mathrm{NH}_{3}-\mathrm{HNO}_{3}-\mathrm{NH}_{4} \mathrm{NO}_{3}$ triad using a wet chemical instrument: an analysis of precision requirements and flux errors, Atmos. Meas. Tech., 3, 187-208, doi:10.5194/amt-3-187-2010, 2010.

Wu, Y.H., Walker, J., Schwede, D., Peters-Lidard, C., Dennis, R., and Robarge, W.: A new model of bi-directional ammonia exchange between the atmosphere and biosphere: Ammonia stomatal compensation point, Agr. Forest Meteorol., 149, 263-280, 2009.
Wyers, P. G. and Erisman, J. W.: Ammonia exchange over coniferous forest, Atmos. Environ., 32, 441-451, 1998.

Yamulki, S., Harrison, R. M., and Goulding, K. W. T.: Ammonia surface-exchange above an agricultural field in Southeast England, Atmos. Environ., 30, 109-118, 1996.

Zahniser, M. S., Nelson, D. D., McManus, J. B., Shorter, J. H., Herndon, S. C., and Jimenez, R.: Development of a Quantum Cascade Laser-Based Detector for Ammonia and Nitric Acid, Medium: ED, Size: 43 pp., 2005. 